University of Louisville

ThinkIR: The University of Louisville's Institutional Repository

Electronic Theses and Dissertations

$12-2005$

\title{
Hanging the moonbow : Tom Wallace and the Cumberland Falls fight, 1926-1931.
}

Noah Garland Huffman 1981-

University of Louisville

Follow this and additional works at: https://ir.library.louisville.edu/etd

\section{Recommended Citation}

Huffman, Noah Garland 1981-, "Hanging the moonbow : Tom Wallace and the Cumberland Falls fight, 1926-1931." (2005). Electronic Theses and Dissertations. Paper 648.

https://doi.org/10.18297/etd/648

This Master's Thesis is brought to you for free and open access by ThinkIR: The University of Louisville's Institutional Repository. It has been accepted for inclusion in Electronic Theses and Dissertations by an authorized administrator of ThinkIR: The University of Louisville's Institutional Repository. This title appears here courtesy of the author, who has retained all other copyrights. For more information, please contact thinkir@louisville.edu. 
HANGING THE MOONBOW: TOM WALLACE AND THE CUMBERLAND FALLS FIGHT, 1925-1931

\author{
By \\ Noah Garland Huffman \\ B.A., Furman University, 2003

\begin{abstract}
A Thesis
Submitted to the Faculty of the

Graduate School of the University of Louisville in Partial Fulfillment of the Requirements for the Degree of
\end{abstract}

\title{
Master of Arts
}

Department of History

University of Louisville

Louisville, Kentucky

December 2005 


\section{DEDICATION}

For their continued support, encouragement, and love, I dedicate this thesis to my

parents - all four of them:

Priscilla Garland and James B. Tennill

and

Richard Huffman and Saundra Huffman 


\section{ACKNOWLEDGEMENTS}

As with any project of this scope, there are a number of people whose insight, support, and encouragement have contributed to the completion of this thesis. First and foremost, I would like to acknowledge Tom Wallace. For the past year and a half I have spent the bulk of my day with Wallace. After reading and cataloging nearly 23 cubic feet and almost 40 years worth of his correspondence, speeches, and editorials, I am still in awe of his intellect, energy, and dedication to service. Truly, as Wallace himself often remarked of Henry Watterson: "There were giants in those days."

Even more than Tom Wallace, however, there are those who have supported me both personally and professionally, without whose guidance and understanding I could never have completed this project. For her persistence, honesty, and encouragement throughout my entire graduate career, I would especially like to thank my advisor Tracy K'Meyer. In the last few months her comments and criticism have improved this thesis immeasurably, and her high standards have made me a better writer and a better historian.

I would also like to thank the other two members of my committee, John T.

Cumbler and John Ferré. Although I met both of them only weeks before my defense, their willingness to serve at the last minute is certainly an indication of their understanding and professionalism. In addition, professors Thomas Mackey, Christine Ehrick, and Wayne Lee have made my graduate career at the University of Louisville an enjoyable and productive one. I would also like to acknowledge the entire history 
department at Furman University, especially professors Erik Ching, Tim Fehler, John Barrington, and Ronald Granieri for their inspiration and dedication to teaching. More than anyone else, they have inspired my intellectual curiosity and convinced me of the enjoyment and value of historical scholarship.

Without the additional support of The Filson Historical Society over the past two years, this project would have been immensely more difficult. By employing me to catalog Wallace's personal papers first as an intern and now as a full-time staff member, The Filson has not only made research for this thesis possible, but also enhanced my appreciation for archives and archivists. Day in and day out, the staff at The Filson have lived with Tom Wallace and Cumberland Falls vicariously through my endless anecdotes and not so subtle segues. Specifically, my friends and coworkers in Special Collections-Jim Holmberg, Elizabeth Kissack, Jacob Lee, Becky Rice, and Mike Veach—have been a constant source of encouragement and a captive audience for all things Wallace.

Last, but certainly not least, I would like to thank my mother, Priscilla Garland, for her unfailing support of my academic pursuits and most importantly for her unconditional love for the past 24 years. More than any other, she has taught me that there are still giants even today. 


\begin{abstract}
HANGING THE MOONBOW: TOM WALLACE AND THE CUMBERLAND FALLS

FIGHT, 1926-1931

Noah Garland Huffman

December 2005

This thesis is an examination of Louisville Times editor Tom Wallace's fight to prevent the construction of a hydroelectric dam at Cumberland Falls, Kentucky between 1926 and 1931. By mining Wallace's recently cataloged personal papers, this study provides a narrative of Wallace's lead role in the campaign that resulted in the preservation of Cumberland Falls and the establishment of a state park on the site in 1931.
\end{abstract}

More importantly, however, as a case study of conservation activism during the understudied period from late 1920s and early 1930s, this thesis illustrates how Wallace developed certain arguments and strategies that were especially effective in confronting the social, political, and cultural currents of the era. As this thesis argues, Wallace's activism highlights a transitional and creative period in the conservation movement's history. By crafting and disseminating arguments in direct response to emerging trends like the consumer economy, the rise in auto tourism and recreation, and the growing public distrust for power trusts and lobbyists, Wallace's activism mobilized a number of interests previously untapped by conservation activists. For this reason, his preservation 
campaign succeeded at Cumberland Falls at a time when conservation activism waned at the national level.

The thesis is divided into five sections, an introduction and four chapters. The introduction situates the Cumberland Falls episode in the broader context of conservation history and considers the historiography of the conservation movement. In addition, it outlines Wallace's arguments and strategies during the Falls campaign and explores why his campaign was ultimately successful. Chapter one has two main objectives. First it provides a brief history of Cumberland Falls prior to the controversy. Second, it considers Wallace's background leading up to the episode. The remaining chapters examine Wallace's role in the complex chain of events that culminated in the preservation of the Falls in 1931. The final chapter also briefly discusses Wallace's rise to prominence and his evolution as a conservationist in the wake of the Cumberland Falls campaign. 
TABLE OF CONTENTS

PAGE

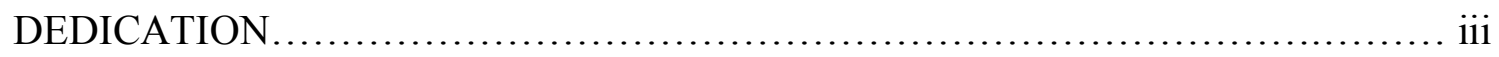

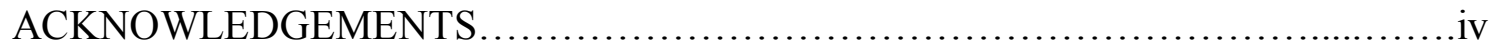

ABSTRACT ..........................................................................

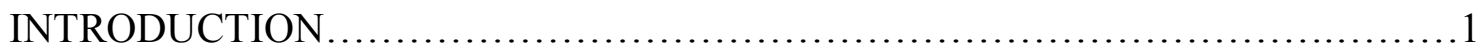

CHAPTER I: CUMBERLAND FALLS “DISCOVERED”..........................17

CHAPTER II: POLITICS AND PROPAGANDA AT KENTUCKY'S “NIAGARA”...35

CHAPTER III: “CAUGHT IN THE POWER NET": CUMBERLAND FALLS ENTERS THE NATIONAL SPOTLIGHT ............................54

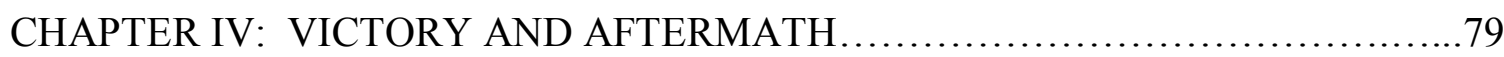

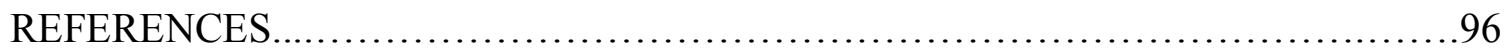

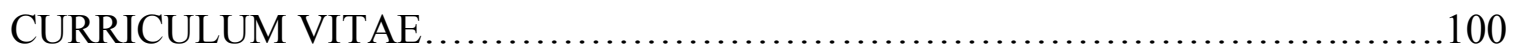




\section{INTRODUCTION}

Between 1926 and 1931 conservationists in Kentucky and across the nation waged a bitter but ultimately successful campaign to prevent the construction of a hydroelectric dam at Cumberland Falls in southeastern Kentucky. At the forefront of that campaign was Tom Wallace, the chief editorial writer for the Louisville Times. Through his visibility and professional contacts with other journalists, conservationists, and politicians, Wallace brought national attention to the Falls case. In the end, through his persistent agitation and advocacy, Wallace amassed enough media attention and political pressure to save the Falls. This thesis is an examination of Wallace's signal role in the fight to save Cumberland Falls.

In addition to providing a narrative of this case, however, this thesis also sheds light on the state of conservation advocacy during the late 1920s and early 1930s. In many surveys of the conservation movement, historians have disregarded this unique period, arguing instead that conservation activism receded after the Progressive era and did not reappear in earnest until the New Deal with federal agencies like the Civilian Conservation Corps and Tennessee Valley Authority. Indeed, Philip Shabecoff suggests in his overview of the environmental movement that after John Muir's death in 1914, "some of the spirit of the preservation movement died." In addition, President

\footnotetext{
${ }^{1}$ Philip Shabecoff, A Fierce Green Fire: The American Environmental Movement (Washington, D.C.: Island Press, 2003), 73.
} 
Coolidge's unabashed support of business in the mid 1920s contributed to an atmosphere where preservation "was not considered an important part of that business by the government and many of its citizens." ${ }^{2}$ Historian Robert Gottlieb agrees, noting the transformations in the federal conservation agenda during the 1920s. "By the close of the Progressive era in the 1920s," Gottlieb argues, "conservation as expertise and rational management of resources for business uses had emerged as the movement's determinant ideology."

Thus, while Shabecoff and Gottlieb accurately point out that preservation did take a back seat on the federal agenda during this period, they fail to consider the few places that it survived--places like Cumberland Falls. Furthermore, while the 1920s provided few public heroes of preservation like John Muir and Theodore Roosevelt, it did witness the emergence of a new cadre of lesser-known activists like Tom Wallace who took up their cause. Although their goals remained largely the same, these newcomers espoused new ideas about "wilderness" and nature, and new theories about how to go about preserving it.

As Paul Sutter argues, too many historians have mistakenly assumed "that the history of preservationist sentiment has evolved from lower to higher forms of appreciation," beginning with early calls from people like Muir and culminating in the environmental activism we are witnessing today. ${ }^{4}$ As the conservation and preservation movements of the 1920s illustrate, this interpretation is flawed. Rather than understanding preservation ideology as some steadily evolving abstract impulse, Sutter

\footnotetext{
${ }^{2}$ Ibid., 74.

${ }^{3}$ Robert Gottlieb, Forcing the Spring: The Transformation of the American Environmental Movement (Washington, D.C.: Island Press, 2005), 60.
} 
suggests that "each era reworks its ideas to fit and reflect contemporary circumstances."5 Borrowing Sutter's interpretation, this case study argues likewise that preservationists during the late 1920s like Tom Wallace developed new arguments and strategies for promoting natural resources and scenic landscapes as a direct response to changing political, social, and cultural currents of the era. Under this interpretation, the years between 1925 and 1931 appear not as a nadir in conservation activism, but rather as a transitional and creative period in which preservationists adapted several emerging trends like the consumer economy, auto tourism, and the growing public distrust of power trusts and lobbyists to suit their own purposes. Moreover, as Tom Wallace's example at Cumberland Falls reveals, successful conservation advocacy in the late 1920s required flexibility and innovation to confront these new impulses. Without these two traits, Wallace would not have been able to build such a broad coalition of support for the Falls at a time when most Kentuckians, and indeed most Americans, remained apathetic to conservation causes.

Born in 1874 in Crittenden County, Kentucky, Tom Wallace lived most of his early life at Ridgeway, his family's 1,500-acre farm on the banks of the Ohio River. His grandfather, Arthur Hooe Wallace, had migrated to Kentucky at the end of the eighteenth century via the Wilderness Road, which passed within a few miles of Cumberland Falls. His father, Thomas Wallace, had fought in the Civil War under Confederate General John Hunt Morgan. Along with his paternal ancestors, Wallace was related to the Hart family, well known for their pioneer exploits with Daniel Boone. The importance of this frontier

\footnotetext{
${ }^{4}$ Paul Sutter, Driven Wild: How the Fight against Automobiles Launched the Modern Wilderness Movement (Seattle: University of Washington Press, 2002), 10.
} 
heritage figured prominently in much of Wallace's writing, and he maintained an appreciation for the pioneer mythos throughout his life. ${ }^{6}$

When he was eleven, Wallace's family left Ridgeway and settled in Shelby County, Kentucky. There, Wallace received instruction from a private tutor before attending Weaver's Business College in Louisville to study accounting. He continued his studies at Randolph Macon College in Virginia, but despite his academic promise, he left school early and took a series of brief jobs as a bookkeeper. While working in Shelbyville, Ky., Richmond, Va., and in a tooth-powder factory in New York City, Wallace discovered that he "hated all kinds of business." Exhausted by the suffocating urbanized and industrialized life he saw overtaking society at the turn of the century, Wallace abandoned his accounting career and set sail with two friends down the coast of Florida on a rickety catboat in search of something authentic and "real" in nature. ${ }^{7}$

Wallace was not alone in this quest for authenticity. Many other Americans during the late 1800 s and early 1900 s also rejected the monotony and detachment of industrial capitalism and embraced a "cult of experience and a craving for "real life." For many social critics, communion with nature and strenuous activity represented this "real" life. Responding to these critics, "a veritable nature craze seized the middle classes of America and Europe at the turn of the century," according to intellectual

${ }^{5}$ Ibid., 10.

${ }^{6}$ In 1935 Wallace served on a committee to celebrate the Daniel Boone's arrival in Kentucky. At the event, which he later referred to as "The Boonesboro Incident," Wallace defended Boone's reputation as the founder of Kentucky and a frontier hero against revisionist claims to the contrary made by historian Dr. Archibald Henderson of the University of North Carolina. The controversy was highly publicized in the media and Wallace gained considerable notoriety for his pro-Boone position. See: Tom Wallace Papers, June-December 1935. The Filson Historical Society (FHS), Louisville, Ky.

${ }^{7}$ See Wallace's unpublished autobiography, Tell Me Not in Mournful Numbers, available at The Filson Historical Society, Louisville, Ky. In this volume Wallace describes his early life ending with his adventures in Florida at the turn of the century.

${ }^{8}$ Sutter, Driven Wild, 21. 
historian David Shi. ${ }^{9}$ At the same time, many writers also promoted physical exertion in nature, rather than monotonous factory work, as "vital both to moral vitality and mental alertness." ${ }^{10}$ Together, these two trends—-towards communion with nature and the strenuous life--formed much of the intellectual foundation for early preservationist theory during the Gilded Age. In John Muir, the rugged wilderness prophet and founder of the Sierra Club, and John Burroughs, the famed nature essayist, these ideas found their most potent expression. As Shi argues, these two men "helped promote both the wilderness conservation movement and the more general interest in outdoor recreation and relaxation among urbanites." ${ }^{11}$ Such ideas were not lost on Tom Wallace.

After a strenuous few months exploring the virtual wilderness of the Florida coast, Wallace returned to Louisville broke and seeking a new career outside of the urban-industrial establishment. He chose journalism and talked his way into an unpaid position as a police reporter at the Louisville Times, the evening companion of the city's Courier-Journal. Six weeks later, he was hired for pay at a rival paper, the Louisville Dispatch. A series of brief reporting jobs followed until legendary Courier-Journal editor Henry Watterson offered Wallace a position on his editorial staff in 1905. Wallace accepted, and became the youngest member of the staff.

Over the next several years, Wallace studied under Watterson, and like his mentor, he developed a reputation for boldness and brevity in his editorials. As editor of the Courier-Journal for some fifty years, Watterson's personality “did much to make the newspaper one of the foremost in the country," according to journalism historian Edwin

\footnotetext{
${ }^{9}$ David Shi, The Simple Life: Plain Living and High Thinking in American Culture (Athens, Ga: University of Georgia Press, 1985), 194-195.

${ }^{10}$ Ibid., 195.

11 Ibid., 195.
} 
Emery. ${ }^{12}$ In addition, Watterson was "a colorful representative of the era of personal journalism and loved to engage in editorial page duels with other editors." ${ }^{, 13}$ Echoing Watterson's editorial philosophy, Wallace would later remark that "editorials should be no longer than a pencil" and "an editorial page without spunk is bunk."

Even more than Watterson's combative style, however, Wallace inherited his appreciation for wilderness and plain living. As John Muir biographer Stephen Fox notes, Watterson was one of the most outspoken advocates during the highly publicized but failed attempt to prevent the damming of the Hetch Hetchy valley in Yosemite. ${ }^{15}$ To what degree Wallace absorbed Watterson's preservationist sentiment is uncertain, but judging from Wallace's general reverence for Watterson, it must have contributed in some way to his development as a conservationist. ${ }^{16}$

In 1910, Wallace married Augusta French, an heiress of the Smith, Kline, French pharmaceutical fortune. After a brief honeymoon in Spain, the couple returned to Kentucky and purchased a large farm along the Ohio River northeast of Louisville in the town of Prospect. On Ronda farm, named after a town in Spain that Wallace had visited during his honeymoon, he supplemented his fast paced journalism career with the solicitude and simplicity of farm life. For Wallace, Ronda Farm provided an escape from the maddening influences of Louisville's hectic and rapidly industrializing city center. Throughout his career, Wallace touted the virtues of rural farm living while maintaining

\footnotetext{
${ }^{12}$ Michael Emery, Edwin Emery, and Nancy L. Roberts, The Press in America: An Interpretive History of the Mass Media, $9^{\text {th }}$ ed. (Boston: Allyn and Bacon, 200), 153.

${ }^{13}$ Ibid., 153.

${ }^{14}$ Wallace's obituary, Courier-Journal, 6 June 1961.

${ }^{15}$ Stephen Fox, John Muir and His Legacy: The American Conservation Movement (Boston: Little, Brown and Company, 1981), 143. Curiously, Watterson is the only journalist Fox names as of the early "preservationists" who supported Muir at Hetch Hetchy.
} 
the busy schedule of a commuting journalist. Wallace was not alone in this choice of lifestyle, as many others had turned to "commuter pastoralism" since the early $1900 \mathrm{~s} .{ }^{17}$

Although the impulses towards simplicity and strenuous living were overwhelmed by a new consumer ethos during the 1920 s, Wallace continued to cling to his turn-of-thecentury ideals. Rising at 4 am to milk his cows and tend to other farm chores, Wallace routinely hauled his milk from his farm in Prospect to markets in Louisville before arriving at his desk at $8 \mathrm{am}$ to begin his editorial work. Wallace admitted that the farm rarely turned a profit and that dealing with his tenants could be taxing. But as David Shi argues, family farms like Wallace's were more important for their symbolic value "as an alternative for city dwellers oppressed by the psychological and economic tensions of metropolitan life."18 Thus, from Wallace's appreciation for his frontier heritage, his rejection of the urban business world, his adventures in the Florida wilderness, and his experiments in strenuous farm living, it is evident that he exhibited a predisposition to conservation activism by the 1920 s.

Before winning national recognition as a conservationist between the 1930s and the 1950s, Wallace began his activism at Cumberland Falls during a time when conservation was a low priority on the public agenda. Indeed, the "Cumberland Falls Fight," as he later referred to it, was a different type of conservation activism, one that was responsive to the prevailing consumer ethos of the 1920s. By the mid-1920s, Muir's moral crusades and appeals to the "romantic sublime" no longer carried the same weight

${ }^{16}$ Throughout his career, Wallace lionized Watterson and took every opportunity to defend the policies and practices of his "revered chief." In 1938, he published a feature article in the Saturday Evening Post titled "There Were Giants in Those Days," in which he praised Watterson's career.

${ }^{17}$ Shi, The Simple Life, 194. 
as they once did. As Shi explains, "the sense of social urgency that had energized turnof-the-century enthusiasts had dissipated by the 1920s."19 In its place, consumerism and individualism ran rampant as Americans gobbled up household appliances and every other product that the good life entailed. ${ }^{20}$ Emery writes, "America was a relatively complacent land, and business, prosperity, and the doings of Wall Street outweighed interest in political or social reform." ${ }^{21}$ President Coolidge echoed the sentiment of the day when he remarked that "the man who builds a factory builds a temple, [and] the man who works there, worships there." 22 When Hoover campaigned for president in 1928, he heralded consumerism and prosperity, proclaiming "two chickens in every pot, two cars in every garage."23 Put simply, by the mid 1920s, "the business of America was business.",24

Fortunately for nature enthusiasts like Tom Wallace, one particular consumer good of the 1920s ironically provided new opportunities for preservationist expressionthe automobile. Once a luxury item for the wealthy, the popularity and affordability of the automobile grew steadily during the 1920s. In 1913 only a million automobiles were registered nationally. By 1922 there were ten million. In 1929, at the height of the Cumberland Falls controversy, the number had grown to 23 million. As Paul Sutter illustrates, this rise in popularity and availability of the automobile had a transformative effect on the wilderness preservation movement. More than any other development, the

\footnotetext{
${ }^{18}$ Ibid., 226.

${ }^{19}$ Ibid., 222.

${ }^{20}$ Samuel P. Hays, Explorations in Environmental History (Pittsburgh, PA: University of
} Pittsburgh Press, 1998), 45. Hays writes that "in the 1920s the age of consumerism came upon us, represented by the mass consumer industry, the automobile, the household appliance. . . "

${ }^{21}$ Emery, The Press in America, 267.

${ }^{22}$ Calvin Coolidge as quoted Shi, The Simple Life, 217.

${ }^{23}$ Hoover as quoted in Emery, The Press in America, 299.

${ }^{24}$ As quoted in Shi, The Simple Life, 217. 
automobile "gave a broad swath of the American populace unprecedented access to exurban nature."25

The automobile and the tourist industry it sprouted in the 1920s and 1930s changed the very concept of wilderness. Whereas during Muir's era, wilderness was something that inspired reverence and reflection, it became during the 1920s something "separate, distant, and exotic" that could be "marked, labeled, and advertised" like a consumer product. ${ }^{26}$ By labeling specific sites with titles of distinction such the "highest" mountain or the "deepest" canyon, postcards, magazines, and guidebooks during the 1920s and 1930s packaged nature for consumption. As a result, tourism, according to Sutter, "became a site specific activity" in which tourists set out to see particular places and "acquire the experience of having done so." 27 With tourists willing to spend both time and money visiting certain scenic attractions, park promoters, entrepreneurs, and even the federal government began to put a dollar value on wilderness itself, solidifying its entrance into American consumer culture. Thus, as Sutter suggests, the rise of consumerism, the automobile, and government sponsorship of roadbuilding, "marked the dawn of a new era in conservation politics, one in which questions about recreational development often overshadowed the tensions between preservation and use" that had divided earlier activists. ${ }^{28}$

Although nature tourism and recreational development resulted in the preservation of certain wilderness areas like Yosemite and Glacier National Park, another aspect of consumerism during the 1920s hampered the efforts of those like Wallace who

\footnotetext{
${ }^{25}$ Sutter, Driven Wild, 24.

${ }^{26}$ Ibid., 28.

${ }^{27}$ Ibid., 27.

${ }^{28}$ Ibid., 16.
} 
fought specifically against scenery-marring dams like the one proposed at Cumberland Falls. That development was the rapid growth in production and consumption of electricity. As Americans outfitted their homes with washing machines, refrigerators, and radios the demand for electricity grew exponentially during the 1920s. In response, private power companies searched for ways to expand production to meet the increased demand. Many companies turned to hydroelectricity and began campaigns to gain control of waterways suitable for hydroelectric dam construction. As environmental historian Samuel Hays explains, by the 1920s "multiple purpose river development" became a catchphrase for power companies. ${ }^{29}$

Cumberland Falls, due to its beauty as well as its hydroelectric potential, became an alluring site for both nature enthusiasts like Tom Wallace and power companies like Samuel Insull's Midwest Utilities Company of Chicago, one of the largest private utility holding companies of the era. As a preservationist and journalist, Wallace was well aware of Kentucky's need for economic development, and he realized early on that the competing needs for scenic tourism and electrical production in the 1920s left the fate of Cumberland Falls precariously in the balance.

Fortunately, like the founders of the Wilderness Society that Sutter describes in Driven Wild, Wallace was also "fully in dialogue with the intellectual ferment and politics of the 1920s and 1930s.."30 By adapting his preservationist crusade at Cumberland Falls in response to the complex political and social terrain of the late 1920s, Wallace was able to generate enough support to save Cumberland Falls from power development. Thus, his preservation campaign highlights the specific types of arguments

\footnotetext{
${ }^{29}$ Samuel P. Hays, Explorations in Environmental History, 5.

${ }^{30}$ William Cronin, "Why Worry about Roads," an introduction to Paul Sutter's Driven Wild, x.
} 
and strategies available to conservation activists during a largely forgotten chapter in the movement's history.

Wallace's arguments on behalf of the Falls can be divided into three broad categories. First were his appeals to the Falls' unique and irreplaceable beauty. In poetic language, Wallace regularly touted the inspiring scenery of the Falls and the surrounding river valley in his editorials, magazine articles, and speeches. He regularly referred to the site as "wild," "unspoiled," "primeval," and "free from artificialization."31 Appealing to the site-specific nature of the tourist industry, Wallace often billed the Falls as "the Niagara of the South," and pointed out the Falls' claim to the only known moonbow in the western hemisphere--a phenomenon caused by the refracted moonlight in the mist surrounding the Falls. ${ }^{32}$

A second category very much related to the first, was Wallace's economic argument concerning the "hard cash" tourist value of the Falls. Wallace frequently noted that, aside from its aesthetic value, the potential economic value of the Falls as a tourist attraction far exceeded its value as a producer of hydroelectricity. He often compared the site to Niagara Falls, which supposedly drew some $\$ 50$ million annually in tourist revenue. This economic argument, however, was predicated on the construction of adequate roads and accommodations in the area for visitors. For this reason, a number of automobile clubs and local chambers of commerce joined Wallace's preservation crusade.

A third category, and perhaps the most effective in the long run, was Wallace's attack on the corporate greed and corrupt practices of private power companies, as well

${ }^{31}$ Tom Wallace, "Caught in the Power Net," Survey Graphic, vol. LXII, no. 7 (July 1, 1929), 389$395,417$. 
as the unscrupulous politicians who bowed to their lobbyists. Interestingly, these arguments were often unrelated to the scenic or tourist value of the Falls, but more in tune with the corporate and political realities of the late 1920s. In a sense, then, Wallace capitalized on the growing distrust for big business that surfaced in the 1920s and transformed it into an argument for saving Cumberland Falls. While he was certainly a preservationist at heart, Wallace was also a realist and an astute observer of social and political trends. When appeals to the Falls' beauty and tourist value failed, he resorted to more potent critiques of Kentucky politicians and evil power trusts. Towards the end of the campaign, this strategy proved highly effective. In February 1930, Wallace wrote to Senator Alben Barkley: "I believe there is a first magnitude scandal in the Cumberland Falls intrigue and propaganda situation in Kentucky.",33

This three-pronged attack allowed Wallace to remain flexible enough to shift arguments and tactics when the situation demanded. As a nationally prominent journalist and media figure, he maintained the visibility and contacts to spread his message and to grease the necessary political gears. Moreover, at a time when the federal and state governments overwhelmingly endorsed business and economic development of any kind, individuals like Tom Wallace were especially critical to the conservation movement's survival. Through their flexibility and notoriety, they kept conservation alive during the 1920s.

Unlike conservationists of the previous era that endorsed either absolute preservation--like John Muir—or conservation for use—like Gifford Pinchot--Wallace and his fellow activists of the 1920s were largely opportunists. They crafted their

\footnotetext{
${ }^{32}$ Ibid., 389-395, 417.

${ }^{33}$ Wallace to Senator Alben W. Barkley, 17 February 1930. Tom Wallace Papers, FHS.
} 
preservationist arguments in response to specific social and political trends of the day, like the emergence of consumerism, the automobile, and scenic tourism. Likewise, they capitalized on the growing public distrust of big business and specifically private utility trusts. What resulted was a type of conservation activism wholly different from anything prior or since. Although it is difficult to gauge whether activists during this period were any more or less effective than in other eras, it is clear that they continued speaking out on behalf of preserving the nation's natural resources and scenic landscapes. As Wallace's campaign at Cumberland Falls illustrates, the mid-1920s were indeed a peculiar but important and transformative period in conservation history.

Rather than provide a thematic analysis of Wallace's three arguments individually, this study instead provides a chronological narrative of the entire Cumberland Falls episode that demonstrates how those arguments were used to respond to specific events. Although the fight to save the Falls between 1926 and 1931 was a complicated and lengthy affair, it can be divided into four main phases, which correspond broadly to shifts between state and federal level activism. For politicians and legislators in Kentucky, and for the Federal Power Commission, which had the authority to approve or deny the dam construction permit, the case presented somewhat of a political hot potato. Thus, the final decision in the case bounced back and forth between the Kentucky state legislature and the Federal Power Commission a number of times due to a complicated and sometimes bizarre chain of events. When it appeared that one body might reach a decision either to save the Falls or to allow the dam, some new development always complicated the matter. Both state and federal authorities routinely 
deferred to each other. This shifting focus between state level and federal level activism, therefore, provides convenient breaks in the narrative and convenient chapter breaks for this thesis.

The first chapter of this study serves two functions. First, it provides a brief history of the Falls prior to the controversy and a detailed description of the dam project as proposed by the Cumberland River Power Corporation in their application for a construction permit in 1926. After establishing this context, the chapter then considers the first statewide efforts to preserve the Falls. These efforts included Wallace's articles and speeches on behalf of the Falls, the local Kiwanis Club's campaign to build an adequate road to the Falls in 1926 and 1927, and the Kentucky General Assembly's 1926 decision not to endorse a bill that would have allowed the recently formed state park commission to acquire the Falls and surrounding land as a state park.

The second chapter traces the development of concern for the Falls outside of Kentucky, particularly as the case came before the Federal Power Commission in 1928. The chapter considers Wallace's efforts to publicize preservationist sentiment in relation to other developments such as Delaware Senator T. Coleman duPont's 1927 offer to purchase the Falls tract and donate it to Kentucky as a state park. With the case pending review by the Federal Power Commission, Wallace publicized the Falls in a series of editorials, articles, and speeches on the subject. He also gathered support for the Falls through his contacts with leaders of national conservation organizations and government agencies from the Izaak Walton League to the National Park Service. This chapter assesses the impact of Wallace's publicity work on galvanizing national support for the Falls as the case awaited review by the Federal Power Commission. 
Chapter three examines the political developments and controversies that handcuffed the Federal Power Commission and caused them to defer again to the Kentucky legislature. At the state level, the chapter considers Wallace's role in exposing Kentucky Governor Flem Sampson's inappropriate dealings with power company lobbyists in the media and through personal contacts with politicians who supported his preservationist position. Although many thought the decision in the case might bounce back to the Power Commission in 1930, Wallace and others determined to influence the Kentucky legislature to act before the Commission could reach a ruling.

The fourth and final chapter addresses Wallace's lead role in arguing on behalf of the Falls during the final showdown with Governor Sampson's pro-dam coalition that took place as the Kentucky legislature deliberated and finally resolved the case in early 1930. By March 1930, Wallace had effectively saved the Falls as the Kentucky General Assembly passed a bill to condemn the area and accept Senator duPont's gift regardless of the power company's outstanding permit application with the Federal Power Commission. Although the case was essentially settled by March 1930, the chapter discusses the remaining issues that had to be resolved at the state level before the Cumberland Falls State Park could be formally established.

Interestingly, as this chapter concludes, Wallace's later activism exhibited a shift in his arguments and theories on park development. While he had initially praised road building and tourism that economically justified the park, he grew to oppose developments like the construction of accommodations for tourists, excess roadways in the park, and the artificial illumination of the Falls, which he believed compromised the "unspoiled" wilderness quality of the area. As this case study argues, however, 
Wallace's changing views of what constituted "wilderness" and his shifting ideas about proper park development were more a reaction to the increased popularity and success of the wilderness preservation ethic on a national scale than an intellectual sea change. In short, Wallace, like most other activists, was more of a barometer of the times than a conservation visionary. Further, what distinguished Wallace from others, especially during the Cumberland Falls episode, was his flexibility and his knack for recognizing and seizing opportunities for promoting his particular conservation agenda in response to the specific social and political realities of the day.

By considering each of Wallace's arguments and strategies in its proper context, this thesis not only tells the story of Cumberland Falls, but also avoids oversimplifying the episode, which could potentially result in dangerous generalizations. Until now, George Robinson's article "Conservation in Kentucky: The Fight To Save Cumberland Falls, 1926-1931" has been the only other scholarly treatment of the topic. ${ }^{34}$ By mining Wallace's personal papers, which were just made available in early 2005 , this thesis expands on Robinson's basic narrative with additional details and analysis of Wallace's lead role in the campaign. It also situates the Cumberland Falls episode within the context of the broader conservation movement during the 1920s. For this reason, this study enhances the literature on both the history of Cumberland Falls and the conservation movement during the late 1920s.

\footnotetext{
${ }^{34}$ George W. Robinson, "Conservation in Kentucky: The Fight to Save Cumberland Falls, 19261931," Register of the Kentucky Historical Society, v.81 no.1 (Winter 1983), 25-58.
} 


\section{CHAPTER I}

\section{CUMBERLAND FALLS “DISCOVERED”}

Some twenty years before the Cumberland Falls controversy, John Muir, the celebrated "wilderness prophet" of Yosemite, conducted a similar fight to prevent the damming of the Hetch Hetchy valley, a glacier carved valley in the Sierra Nevada east of San Francisco, which Muir described as a "landscape fresh from God's hand." Although Muir and his fellow preservationists suffered defeat, their highly publicized campaign against the "temple destroyers" at Hetch Hetchy proved to be one of the watershed events in conservation history. In fact, many historians describe the controversy as the first successful attempt at building popular support for conservation projects nationwide. According to Roderick Nash, "the wilderness movement began, in earnest, with Hetch Hetchy."2

As the social activism of the Progressive Era gave way to the individualistic consumer ethos of the 1920s, however, most Americans dismissed preservationist sentiment like Muir's. Fortunately, however, a few dedicated amateurs like Tom Wallace fought to keep Muir's tradition alive. In a remote region of southeastern Kentucky between 1925-1931, Cumberland Falls was the site of arguably the most complicated and contentious conservation battle in Kentucky's history. According to Wallace, it was also

${ }^{1}$ As quoted in Stephen Fox, John Muir and His Legacy: The American Conservation Movement (Boston: Little, Brown, And Company, 1981), 21. 
"one of the most heated and dramatic events in the annals of the Kentucky Legislature."3 Like Hetch Hetchy for John Muir, the Cumberland Falls controversy pitted Wallace and his supporters against powerful pro-dam advocates, in what would become a bitter fiveyear struggle for public and political support that captivated the national conservation community. In the course of the dispute, Wallace devoted the bulk of his time and energy to saving the Falls. In 1927 he wrote to a fellow editor, "I am almost detached from my regular job ... and I am working night and day to keep the project going and at the same time keep my editorial work in shape." ${ }^{4}$ Largely through Wallace's efforts, conservationists achieved a monumental victory at Cumberland Falls, preventing the construction of the dam and establishing a state park on the site.

To provide context for the height of Wallace's activism between 1927 and 1930, this chapter serves two purposes. First, it gives a brief history and description of the Falls area leading up to the Kentucky legislature's March 9, 1926 decision not to acquire the Falls for park purposes. Part of that history includes the specifics of the power company's dam proposal as well as early calls for a state park on the site. Although the road building efforts of the Kiwanis Club of Corbin did not conclude until 1927, the year after the legislature's decision, they are also considered here as context for Wallace's later activism. Secondly, this chapter highlights Wallace's early efforts to generate support for the Falls through editorials and speeches across the state. Although they were powerful in their own right, Wallace's early outcries ultimately had little impact on public opinion or on the 1926 state senate decision.

\footnotetext{
${ }^{2}$ Roderick Nash, Wilderness and the American Mind, $4^{\text {th }}$ ed. (New Haven: Yale University Press, 2001), 180 .

${ }^{3}$ Ibid., 143.
} 
Prior to the protracted controversy between 1926 and 1931 very few people, Kentuckians or otherwise, had ever visited Cumberland Falls. Located on a horseshoe bend in the Cumberland River roughly 12 miles below the small town of Williamsburg, the Falls straddle Whitley and McCreary counties and measure between 65 and 80 feet in height depending on the season. With a 125-foot wide curtain of water, Cumberland Falls is the largest waterfall in Kentucky and the largest between the Appalachians and the Rockies. ${ }^{5}$ State geologist Dr. Willard Rouse Jillson vividly described the scene in a 1924 study:

The region is a wild and picturesque one. The Cumberland River comes down gracefully from the Pine and Cumberland Mountains flanked on either side by majestic forested hills, and plunges in wild and splendid beauty over a single conglomeratic ledge of the Lee sandstone. . . . Below the falls is developed a deep gorge, narrow, boulder choked and torturous in figure. The placid reaches of shallow and occasional riffle above the falls are strangely contrasted with the violent swirls and currents of the river chasm immediately beneath and on down through the narrow confines of this wild and little frequented gorge. ${ }^{6}$

Similarly, Vance Prather, Kentucky's First State Park Commissioner, noted that the Falls area "forms one of the unique scenic spots and one of the finest natural playgrounds to be found in all America." 7 Perhaps more than its size, the Falls were and are still best known for the moonbow - a peculiar phenomenon caused by refraction of moonlight in the mist of the falls visible only during certain lunar stages. Victoria Falls in Africa is the

\footnotetext{
${ }^{4}$ Wallace to Marvin H. Creager, Secretary of the American Society of Newspaper Editors, 17 December 1927. Tom Wallace Papers, The Filson Historical Society (FHS), Louisville, Ky.

${ }^{5}$ Vance Prather, "Kentucky Seeks to Save Falls," The New York Times, 11 April 1926; Williamsburg Commercial Club, Facts About Cumberland Falls, Pamphlet, 1929. FHS.

${ }^{6}$ Jillson, W.R. Kentucky State Parks (1924) as quoted in "Report of the Special Committee on The Cumberland River Falls Power Project," a pamphlet printed by the Engineers and Architects Club of Louisville, 16 November 1926. The Filson Historical Society, Louisville, Ky.

${ }^{7}$ Vance Prather, "Kentucky Seeks to Save Falls," The New York Times, 11 April 1926.
} 
only other waterfall known to produce a moonbow. ${ }^{8}$ Because of its geologic distinctiveness and its natural abundance of flora and fauna, Prather argued in 1926 that "Preservation of Cumberland Falls is imperative for a state park or state or national game preserve for the future."

Had more Kentuckians visited the Falls, they might have supported Prather and other early park advocates. Before the 1920s, however, few knew the beauty of Cumberland Falls. Although the Brunson family operated the Moonbow Inn near the Falls, which had functioned as a small summer resort since the Civil War, the rugged terrain surrounding the area and its distance from any sizeable metropolis made the site relatively inaccessible to day-trippers. ${ }^{10}$ In fact, the only access to the Falls other than on foot or horseback was a rudimentary thirteen-mile logging trail that in the 1920s was described as "almost impassable."11 According to the intrepid few who had visited the Falls, though, the cataract was second only to Niagara. Indeed, many visitors began to refer to the site as "the Niagara of the South," an oft-repeated label that served as a potent symbol for conservationists during the entire dispute. ${ }^{12}$

Due to the emergence of the "good roads movement" in 1912 and the rise in the popularity and availability of the automobile in the 1920s, attitudes towards scenic sites like waterfalls began to change considerably. Responding to these developments, early park advocates like Stephen Mather and Horace Albright touted the tourist possibilities of

\footnotetext{
${ }^{8}$ Lois Purcell Noel, Cumberland Falls, Pamphlet, 1932. FHS.

${ }^{9}$ The New York Times, 11 April 1926.

${ }^{10}$ In a 1932 pamphlet titled simply "Cumberland Falls," Lois Purcell Noel describes the Moonbow Inn as "a rambling two-story frame structure with 100 outside rooms, all opening on wide verandas surrounding the building on each level." FHS.

${ }^{11}$ Harlean James, "How Corbin Discovered Cumberland Falls," The Review of Reviews, 79 (1929), 72.

12 Ibid., 72.
} 
such sites. ${ }^{13}$ Moreover, as sociologist Andrew Tuxwell wrote in 1927, "the automobile has made possible an extent of tourist travel heretofore unknown and the movement for state parks which is a phenomenon of the present time, is a movement to meet the needs of this touring populace." 14

Together, the national impulses towards road construction, tourism, and state park development caused some Kentuckians to reconsider the value of Cumberland Falls. As with most other trends, however, Kentucky lagged behind most states. By 1918, Kentucky had only 214 miles classified as state highways. As noted Kentucky historian Thomas D. Clark writes, at the end of World War I, Kentucky had "only a faint tracery of improved roads." $" 15$ Despite these setbacks, residents and businessmen in nearby Corbin, Kentucky speculated that the Falls could be a potential economic asset to their community. Accordingly, a few enterprising leaders of the local Kiwanis Club of Corbin put together a tourist brochure in 1926 touting the beauty of the Falls, and they began a fundraising campaign to build a better road to the site. ${ }^{16}$

In 1927, after the Cumberland Falls controversy had raged for roughly a year, four members of the Corbin Kiwanis Club, later dubbed the "Four Horsemen," set out in their specially equipped Model T Ford and attempted to demonstrate that the Falls could

${ }^{13}$ In 1921 Mather helped form the National Conference on State Parks with its motto "A State Park Every Hundred Miles." Similarly, in 1924 and 1926 President Coolidge organized the National Conference on Outdoor Recreation, intended to demonstrate that the federal government was taking a more active role in encouraging outdoor recreation. See Sutter, Driven Wild, 37-41.

${ }^{14}$ As quoted in Sutter, Driven Wild: How the Fight against Automobiles Launched the Modern Wilderness Movement (Seattle: University of Washington Press, 2002), 37-38.

${ }^{15}$ Thomas D. Clark, History of Kentucky (Ashland, KY: Jesse Stuart Foundation Press, 1992), 466.

${ }^{16}$ George W. Robinson, "Conservation in Kentucky: The Fight to Save Cumberland Falls, 19261931," Register of the Kentucky Historical Society, v. 81 no. 1 (Winter 1983), 26-27. Kiwanis Club members supporting the road project included banker Robert A. Blair, printer Tom Gallagher, car dealer Wade Candler, and grocer Ira Chitwood. Blair was certainly the most vocal of these, and he contributed much to the overall campaign often serving as Wallace's local informant on developments in Corbin. The 
be reached by automobile. Carrying a sign proclaiming "We want a good road to Cumberland Falls," the group also hoped to attract publicity to their cause. Although it took a little over five hours, the Kiwanians managed to navigate the treacherous eighteenmile distance and reach the Falls. ${ }^{17}$ Their publicity campaign, however, was not as successful as they had planned. According to Harlean James, the Executive Secretary of the American Civic Association who visited the Falls in early 1928 while preparing for an article on the road building campaign, the Kiwanis Club simply "had no money."18 Persuading the state to allocate funds for the road would have also been a time consuming and likely unproductive effort as many of the state's existing roads were in desperate need of hard surface.

Indebted, the Kiwanians embarked on an improbable campaign. They determined to build the road themselves. ${ }^{19}$ In the late summer of 1927, they put together an "emergency volunteer road crew" composed of club members and others in the community who supported the project. Taking three weeks vacation from their day jobs, the energetic road crew labored long hours creating "across the deep-cut valleys and along the wooded ridge a skyline road, which revealed glimpses of the tier on tier of mountain ranges across the rough ravines." ${ }^{, 20}$ Although they had managed to convince the highway department to loan some road machinery, most of the work was done "with simple hand tools and farm implements." Close to the Falls, a sharp valley provided added difficulty for the amateur road builders. After calling on a railroad engineer,

Bob Blair Museum in Cumberland Falls State Park now honors Blair's contribution to the campaign and his continued support for Cumberland Falls State Park throughout his life.

${ }^{17}$ Ibid., 26-27.

${ }^{18}$ Harlean James, "How Corbin Discovered Cumberland Falls," 73.

${ }^{19}$ Ibid., 73.

${ }^{20}$ Ibid., 73 . 
however, the group managed to construct "a sturdy rustic bridge of unusual length and real beauty." According to reports, the bridge could support a ten-ton truck. In just three weeks, the homemade road to the Falls was complete, and it opened for traffic amid much fanfare on September 22, 1927.

In the following weeks, over 2,000 cars made their way to the Falls on the new road, which reduced the driving time from Corbin to roughly two hours. A year later, Harlean James made the trip. "When we reached the rustic bridge," she proclaimed "we could hear the roar of the falls still some distance away." ${ }^{21}$ Describing the trip in a February 1929 edition of The Review of Reviews, James wrote: “The waters fall like a finely woven medieval lace net set with jewels, the selvage edge as plainly marked as though the marvelous fabric were being reeled relentlessly from a giant loom." ${ }^{22}$ She concluded by declaring the Falls "eminently suited for a State Park that would achieve fame far beyond the borders of the state. ${ }^{23}$

Despite the completion of the road and the publicity it brought to the Falls, the site was still largely "undiscovered" by outsiders—but not by Samuel Insull. As head of the Midwestern Utilitities Company of Chicago and one of the richest men in America at the time, Insull had had his eye on the Falls since 1924. That year he formed a subsidiary, the Cumberland River Power Company (CRPC), and obtained a temporary permit from the Federal Power Commission to study the feasibility of a hydroelectric dam at the cataract. Established in 1920 by the Federal Water Power Act, the Federal Power Commission was composed of the secretaries of war, the interior, and agriculture. Having jurisdiction over "navigable waterways," the Commission held the authority to

\footnotetext{
${ }^{21}$ Ibid., 74.

${ }^{22}$ Ibid., 74.
} 
grant licenses to power companies wishing to construct power dams on such

waterways. ${ }^{24}$ In addition to the temporary permit application, Insull purchased an option to buy the Falls and surrounding land from the Brunson family should the Power Commission grant a permanent license.

For Insull, and other power magnates of the era, hydroelectricity was the wave of the future. As conservation historian Samuel Hays writes, by the 1920s, "unharnessed rivers flowing to the ocean without being used by man were deplored as wasteful; they could be made far more productive if brought under control by large scale public works such as dams and reservoirs. ${ }^{25}$ Indeed, construction of famed Hoover Dam on the Colorado River began in 1928. To capitalize on this attitude and the increased demand for electricity, Insull and others quickly acquired rights to waterways that might be suitable for hydroelectric production. By 1926, Insull's midwestern utilities empire was at the forefront of this charge, and at the same time that the Kiwanis Club was kicking off their road building propaganda, Insull's CRPC concluded preliminary studies and determined that Cumberland Falls would be an ideal site for a dam. ${ }^{26}$

Wasting no time, Robert G. Gordon, an attorney in Louisville and local counsel for the CRPC, filed an application with the Federal Power Commission on March 9, 1926 for a permanent license to develop the Cumberland Falls site. The application called for a primary concrete dam about eighty feet high and 800 feet long that would span the entire width of the Cumberland River some 3,500 feet above the falls. Also included were plans for a second and smaller Weir dam just below the main dam. The face of the

\footnotetext{
23 Ibid., 74.

${ }^{24}$ Robinson, "Conservation in Kentucky," 28.

${ }^{25}$ Samuel P. Hays, Explorations in Environmental History (Pittsburgh: University of Pittsburgh Press, 1998), 5.
} 
larger dam would arch back about 400 feet, impounding the water behind it and creating an artificial lake extending some thirty miles upstream. According to company spokesmen, the artificial lakes would provide recreational opportunities for fisherman, duck hunters, and boaters of all kinds. ${ }^{27}$

In the face of the dam, twenty-four spillway gates would regulate the flow of water released over the dam, but the majority of water behind the dam would be diverted around the Falls through a 2,200-foot-long and 19-foot-wide tunnel bored straight through the base of the adjacent mountainside. Bypassing the falls and dropping 150 feet in elevation, the rushing water would travel through the tunnel to a powerhouse located on the river 4,800 feet below the Falls. Here, the water would turn two 20,000 horsepower vertical turbine generators. The resulting 40,000 horsepower output would be carried by a 132,000-volt transmission line some thirty miles to London, Kentucky where it would enter the main grid of the Kentucky Utilities Company. Insull representatives estimated the project would take two years to complete and cost approximately $\$ 6$ million. ${ }^{28}$ They also insisted that both the dam and the power station would be out of view of the falls and therefore not damage the scenic beauty of the cataract. According to Lois Noel Purcell, however, one facetious observer remarked that "the falls themselves would also be out of sight—in the tunnel."29 Company spokesmen downplayed these flow reduction issues and instead touted the benefits that the dam would provide in the way of flood control and recreation. Additionally, they promised to

\footnotetext{
${ }^{26}$ Robinson, "Conservation in Kentucky," 29.

${ }^{27}$ Engineers and Architects Club of Louisville, "Report of the Special Committee on the
} Cumberland River Falls Power Project," 16 November 1926. Pamphlet held at The Filson Historical Society, Louisville, Ky. The pamphlet includes a summary of the application of the Cumberland Development Company.

${ }^{28}$ Lois Purcell Noel, Cumberland Falls, Pamphlet, 1932. FHS.

${ }^{29}$ Ibid. 
"set aside free fifty acres or more of land for park purposes" and to illuminate the Falls at night. ${ }^{30}$ Conservationists were immediately suspicious of the proposal, and they feared the company would transform the area into "a miniature Coney Island.",31

Put in perspective, the Cumberland Falls project was not the only hydroelectric dam slated for construction in Kentucky at the time, nor was it the largest. In fact, construction began in 1926 on a 135,000 horsepower hydroelectric dam at the Falls of the Ohio near Louisville, which the Federal Power Commission had approved three years earlier. These ambitious plans called for an 8,650 foot long dam approximately twenty feet high that would "improve navigation" and create "a great harborage for freight and passenger vessels" according to promotional literature distributed by the Louisville Hydro-Electric Company. ${ }^{32}$ Initially, the Cumberland Falls dam was to serve only as an auxiliary power producer to the larger Ohio River dam. By comparison, the Cumberland dam would provide less than a third of the energy output of the Falls of the Ohio dam, but because of its location on a much smaller waterway, the Cumberland Falls dam would more dramatically disrupt stream flow and thus effectively destroy a scenic waterfall. ${ }^{33}$

Understandably, some nearby organizations and residents expressed early concerns over hydroelectric development at Cumberland Falls. The company assured them, however, that construction jobs and abundant electricity would spur much needed economic development in the region. A report on the dam endorsed by the Williamsburg Commercial Club and other prominent business and professional men of Whitley and

${ }^{30}$ Engineers and Architects Club of Louisville, "Report of the Special Committee on the Cumberland River Falls Power Project," 4.

${ }^{31}$ Lois Purcell Noel, Cumberland Falls, 6.

32 "Power Development at Ohio River Falls," from a brochure distributed by Byllesby Engineering and Management Corporation, 1926. FHS.

${ }^{33}$ Ibid. 
McCreary counties lauded the project because it "harnessed tremendous but wasted power and put it into the service of the state. ${ }^{34}$ Besides, the report concluded, the Falls area was "non arable and largely uninhabited," and thus, "of little value at present." those who did question the dam's impact on the integrity of the Falls and the surrounding scenery, the company promised "a fair average flow of water over the Falls at all seasons. ${ }^{36}$ While it is difficult to gauge the attitudes of the isolated residents of Eastern Kentucky towards the project, it is assumed that most either acquiesced initially and looked forward to the economic boost that the project would bring, or remained apathetic to the issue entirely.

Indeed, in 1926 the conservation movement had made few inroads in Kentucky. Although a state park commission was established in 1924 to keep pace with other states, its program was woefully underfunded. Not until 1926 did the state begin establishing state parks under the direction of Willard Rouse Jillson, the state geologist. Even then, Jillson was only given "the magnificent budget of $\$ 1,100$ for his first year" as head of the state park commission. ${ }^{37}$ Despite Jillson's relative success with such little funding, the parks remained into the 1940s "a collection of undeveloped nature sites, with a couple of lodges and some cabins and roads built by the CCC." ${ }^{, 38}$ What Kentucky needed in the 1920s, was "investment capital, automobiles, good roads," and most importantly, "organized pressure groups to represent these elements." 39 At the time, there was nothing

${ }^{34}$ Williamsburg Commercial Club, Facts About Cumberland Falls, Pamphlet, 1929. FHS.

${ }^{35}$ Ibid.

${ }^{36}$ Engineers and Architects Club of Louisville, "Report of the Special Committee. .."

${ }^{37}$ John Ed Pearce, Divide and Dissent: Kentucky Politics, 1930-1963 (Lexington, KY: University of Kentucky Press, 1987), 51.

${ }^{38}$ Ibid., 51.

${ }^{39}$ Ibid., 26. 
of the sort in the state, as only a handful of Kentuckians like Tom Wallace expressed any interest in preservation over commercial development.

And so, by late 1926, what was previously a relatively unknown waterfall in the backwoods of Kentucky now had two competing interests vying for its control. On one hand, a few enlightened businessmen, Kiwanis Club members, and conservationists envisioned a park that could potentially draw tourist dollars to the region, while on the other, power advocates promised a dam that would bring cheap electricity and industrial development to an impoverished region of the Commonwealth. At the time, most Kentuckians remained largely undecided on the issue, but those near the dam tended to view the construction project as an economic elixir. ${ }^{40}$ It was in this atmosphere that a 52year-old Tom Wallace began what he would later define as the most difficult but important conservation crusade of his entire career.

Initially a supporter of hydroelectric power development, as he later confessed in a 1928 letter, Wallace changed his view with regard to Cumberland Falls after he discovered the windfalls in tourist revenues that other states were reaping from similar scenic attractions like Niagara Falls. ${ }^{41}$ Shortly after Insull's Cumberland River Power Company applied for a permanent license to build the dam in 1926, as Wallace recalled, a press agent visited his office and assured him that the Falls were nothing more than "a

${ }^{40}$ Determining local public opinion towards the dam project is difficult. Organizations such as the Williamsburg Commercial Club supported the dam, as did most other businessmen in the area. According to Robert F. Sexton, future Governor Flem Sampson and Kentucky Congressman John Robsion, both natives of southeastern Kentucky, had managed to build "an eastern Kentucky faction of the Republican Party" by the mid-1920s. Both Sampson and Robsion supported the dam, and so it is likely that their constituents did as well. See: Williamsburg Commercial Club, Facts About Cumberland Falls, Pamphlet, 1929, FHS; and Robert F. Sexton, "Flem D. Sampson," in Lowell Harrison, ed., Kentucky Governors (Lexington, KY: University Press of Kentucky, 2004), 160-163. 
sewer for mining camps." ${ }^{, 42}$ Incensed by such false propaganda spread by power agents, Wallace decided to strike back with his own propaganda. Under his editorial leadership, the Louisville Times published a number of editorials on the subject in 1926, most of them written personally by Wallace.

As an editorial writer trained under Henry Watterson, Wallace was ideally suited to conduct an editorial crusade on behalf of the Falls. To help matters, he had the support of his employer Robert W. Bingham, owner and publisher of The Courier-Journal and Louisville Times. Formerly a judge in Louisville, Bingham had married Mary Lily Flagler in 1916, the widow of the late Henry Flagler, the richest man in America. Less than a year after their marriage, Mary suddenly died leaving Judge Bingham a handsome $\$ 5$ million portion of her estate. Later that same year, Bingham used the inheritance to purchase the Courier-Journal and Louisville Times from the Haldeman family. ${ }^{43}$ Although the Haldemans had owned and operated both papers since their inception, it was Henry Watterson who brought national attention to the enterprise. Arguably the most famous editor of his era, Watterson was, according to Marie Brenner, "an Edwardian, a globe-trotter and a friend of prime ministers and presidents, a literate windbag, forceful and didactic, still fighting the Civil War." ${ }^{44}$ Once a veritable celebrity, Watterson's reputation had dwindled by the time Bingham took control. The two clashed early and often as Bingham attempted to shift the editorial philosophy of the papers in a

${ }^{41}$ Wallace to Richard Woods Edmonds, publisher of "The Manufacturers Record," 24 March 1928, Tom Wallace Papers, FHS.

${ }^{42}$ Ibid.

${ }^{43}$ Marie Brenner, House of Dreams: The Bingham Family of Louisville. (New York: Random House, 1988.), 22.

${ }^{44}$ Ibid., 132. 
more liberal direction. In 1919, Watterson had had enough and he resigned over Bingham's support of the League of Nations.

As an avid hunter, part of Bingham's plan for the paper included supporting progressive issues like conservation. From the beginning he encouraged Wallace's conservation activities by both granting him an unusually high level of editorial freedom and providing him with the time and money to attend conferences and other speaking engagements. In April 1925, just before the onset of the Cumberland Falls controversy, Bingham wrote to Wallace affirming his support. "You have brought nation-wide recognition to the papers in the work you have done in this general direction," the judge remarked, "and I think it is really important for you to keep in touch personally with the other leaders in this and similar projects. ${ }^{, 45}$ With Bingham's financial and editorial support, Wallace maintained a flexible work schedule and a generous expense account during the entire Cumberland Falls affair.

In early March 1926, Wallace, for the first time, forcefully laid out his entire argument for saving the Falls in a four-page article published in American Forests, the national magazine of the American Forestry Association. Despite illustrations that highlighted the beauty of the Falls and poetic descriptions of the area as an "enchanting wilderness," Wallace argued specifically that "beauty spots, and scenes of grandeur ... should be considered with regard to their cash value." ${ }^{\text {"6 }}$ He added, "sentiments aside, conservation is business. ${ }^{47}$ In a sense, Wallace sought to dismantle the fundamental argument of the pro-dammers - that preserving the Falls purely for its scenery would deprive the region of the economic benefits of a power dam. Although he clearly

\footnotetext{
${ }^{45}$ Robert W. Bingham to Wallace, 24 April 1925. Tom Wallace Papers, FHS.

${ }^{46}$ Tom Wallace, "The Case of Cumberland Falls," American Forests (March, 1926), 145.
} 
appreciated the scenic beauty of the Falls, Wallace put his aesthetic sensibilities on hold to make a more universally appealing economic argument tied to the recreational and tourist possibilities of a park at the site. In doing so, he mirrored the transformations that conservation advocacy was undergoing in the mid-1920s. During the 1920s, as Mark Harvey argues, "interest in the parks sprang more from recreational opportunities than from a strong commitment to protecting their resources. ${ }^{.48}$

In addition to touting the tourist value of a park, Wallace questioned the power company's rationale for locating the dam so near the Falls. "Kentucky has 12,000 miles of streams, many of them fit for power development," Wallace argued; "It has only one Cumberland Falls. ${ }^{, 49}$ Interestingly, Wallace did not utterly discount the benefits of hydroelectric dams in Kentucky; he merely questioned the company's logic in locating the dam in such a picturesque and irreplaceable natural landscape. Likewise, he questioned the recreational benefits of the proposed lake impoundment behind the dam. While the company promised pristine lakes suitable for fishing, hunting, and boating, Wallace pointed out that seasonal variations in water levels caused by the company's flow scheme would contribute to unsightly shorelines and potentially hazardous health conditions..$^{50}$

While Wallace merely echoed the arguments of other conservationists with regard to these recreation impoundments, his arguments on behalf of the "cash value" of the Falls were especially powerful. Soon a highway would be completed between Cincinnati and Lookout Mountain in Tennessee, Wallace argued, and thousands of tourists would

\footnotetext{
${ }^{47}$ Ibid., 145.

${ }^{48}$ Mark W.T. Harvey, A Symbol of Wilderness: Echo Park Dam and the American Conservation Movement (Albuquerque: University of New Mexico Press, 1994), 288.

${ }^{49}$ Wallace, "The Case of Cumberland Falls," 146.
} 
pass through the region. Before long, Wallace estimated that the Falls could generate as much as $\$ 1$ million annually. Therefore, in addition to saving the Falls for their aweinspiring scenery, Wallace suggested that Kentuckians should "look at it as ... Sam Goldwyn looks at pictures"—as a profitable tourist site. Concluding his American Forests article, Wallace asked: "Would it pay to sacrifice the Falls?",51

Although the article most likely reached only a small and already committed audience of conservationists, it caught the attention of Stephen Mather, the director of the National Park Service and one of the nation's most respected conservationists. Mather began his career as a journalist with the New York Sun from 1887 to 1893, but later made a sizeable fortune mining and marketing borax. After retiring in 1913, Mather decided that after profiting off of "the soil of the country," he should instead be "putting a little of

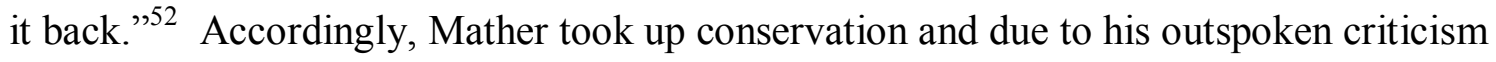
of the early National Park System he was eventually challenged by Secretary of the Interior Franklin K. Lane to come "run them yourself." In 1915, he was appointed assistant to the Secretary, and in 1917 he became the first Director of the National Park Service, a post he held until illness forced him to retire in 1928. As Park Service Director and a founder of the National Conference of State Parks, Mather was arguably responsible for preserving more parks and recreation areas than any other individual during the 1920 s. $^{53}$

Therefore, when Mather wrote to Wallace on March 11 acknowledging the article and congratulating him for making "a splendid case for the Falls," Wallace knew he had

\footnotetext{
${ }^{50}$ Ibid., 146.

${ }^{51}$ Ibid., 148.

${ }^{52}$ Fox, John Muir and His Legacy, 146.
} 
gained a powerful ally in the fight. Mather compared the public attitude towards saving the Falls in Kentucky to the case of Jackson Lake in the Tetons, which was "ruined before the people as a whole knew of its beauty. ${ }^{, 54}$ In the Cumberland Falls case, however, Mather saw reason for optimism. "Now that the automobile roads are opening up the country," he argued, "people are very bitter at the destruction that has been caused." ${ }^{55}$ Thus, if enough people visited the Falls in person, Mather reasoned, they would surely support its preservation. Although Mather died in 1930 just months before the controversy was resolved, he remained one of Wallace's closest allies and confidants throughout the fight.

Largely unrelated to Wallace's publicity efforts and Mather's attention, it appeared on March 9, 1926 that the Kentucky General Assembly might take action to protect the Falls on their own accord when Senator Samuel W. Adams of Covington introduced a bill that would have granted to the state the right of eminent domain over the Falls tract. If passed, the bill would have effectively given the state park commission exclusive authority to purchase the Falls despite the power company's outstanding option on the property. Although Governor William J. Fields endorsed the bill, the Senate voted against it, concluding that the state park commission lacked sufficient funds to pay for the land even if it was declared eminent domain. ${ }^{56}$ While some Senators clearly preferred the dam, the majority conceded that the park project was just too expensive for the state park commission to afford.

\footnotetext{
${ }^{53}$ Henry Clepper, ed., Leaders of American Conservation (New York: Ronald Press Company, 1971), 222.

${ }^{54}$ Stephen Mather to Wallace, 11 March 1926. Tom Wallace Papers, FHS.

${ }^{55}$ Ibid., 11 March 1926.

${ }^{56}$ Robinson, Conservation in Kentucky, 31.
} 
Despite the sincerity on behalf of some of the senators, the vote indicated to Wallace that outside pressure had swayed the opinion of the assembly. ${ }^{57}$ With their seemingly unlimited funds and established network of lobbyists, the Insull power interests, in Wallace's view, had engineered the 1926 senate decision. Despite his early efforts in editorials and speeches to bring attention to the beauty of the Falls and to the potential profitability of a state park at the site, Wallace realized that conservationists in Kentucky still remained disorganized and moneyless. Meanwhile, the Insull interests, as Wallace later remarked, maintained "expensive lobbies in every state capital" and were "probably greater than the oil interests in financial power." 58

Because the state had refused to take action to save the Falls in March 1926, the case transferred to the Federal Power Commission, who had final authority either to grant or deny the power company's permit application. As a national issue, the situation at Cumberland Falls took on added significance and it served as a barometer for conservation feeling nationwide throughout the remainder of the 1920s. As the New York Times reported in October 1927, the case demonstrated that "there is a fine line between the necessities of commerce and the aesthetic needs of civilization." ${ }^{59}$ As Wallace embarked on a new phase of activism at the national level, however, he blurred these boundaries between aesthetics and commerce. In the process, he mobilized support for the Falls from a variety of interests previously unrecognized by conservationists.

\footnotetext{
${ }^{57}$ New York Times, 4 April 1926.

${ }^{58}$ Tom Wallace, “Caught in the Power Net," Survey Graphic, vol. 62 no. 7 (1 July 1929), 394.

${ }^{59}$ New York Times, 15 October 1927.
} 


\title{
CHAPTER II
}

\section{POLITICS AND PROPAGANDA AT KENTUCKY'S NIAGARA}

\begin{abstract}
Although Wallace promoted preservation of the Falls leading up to the state legislature's March 1926 vote, he was not surprised when the eminent domain bill failed to pass. In January 1927, he remarked that in Kentucky "politics has always been a hindrance." ${ }^{1}$ With the case under review by the Federal Power Commission, Wallace took his campaign to a national audience- one that he hoped would be more sympathetic to his cause. To defeat the powerful and highly organized Insull lobby, Wallace needed to build an equally impressive coalition of conservationists. More immediately, however, he needed to convince the Federal Power Commission to deny the permit or at least delay a decision until the state legislature shifted its opinion on the issue. To achieve these ends, Wallace embarked on a two-front propaganda campaign to discredit both the concept of a dam at the Falls and the underhanded tactics of those who supported one. On one front, Wallace used his editorials, articles, and speaking engagements to bring media attention to the issue. On the other, he slowly built an impressive support base that included national conservation organizations and sympathetic politicians who could use their prominence to lobby the Federal Power Commission on his behalf. ${ }^{2}$
\end{abstract}

\footnotetext{
${ }^{1}$ Wallace to I.E. Hodge, 3 January 1927. Tom Wallace Papers, The Filson Historical Society (FHS), Louisville, Ky.

${ }^{2}$ Wallace himself later identified these two fronts in "Saving Cumberland Falls," American Planning and Civic Annual v. II (Harrisburg, PA: Mount Pleasant Press, 1930), 141.
} 
On April 3, 1926, Wallace traveled to New York City, which he considered an appropriate place to launch his national preservation campaign. Speaking to the New York Federation of Women's Clubs at their John Burroughs Day Celebration, Wallace began by lauding Burroughs' unequaled talents as a writer and his appreciation for wilderness. "He went into the wilderness as into a university or a temple," Wallace remarked. Quickly, though, Wallace shifted the focus of his address from an elegy to the late Burroughs to a tactful and vigorous defense of preserving Cumberland Falls. "It seems appropriate upon this occasion to discuss sparkling water," Wallace transitioned. Comparing Cumberland Falls to Niagara, Wallace concluded that both were "the champagne of the wilderness." As such, he argued that each should be preserved not only for their intrinsic scenic value but also because "waterfalls, as public reservations, are sound investments." If Niagara generated $\$ 50$ million in annual tourist revenue, as Wallace cited, then certainly Cumberland Falls could generate a similar amount as "the largest cataract, except Niagara, east of the Mississippi." If so, Wallace argued, the Falls should be saved not only because it was "in a wild mountain gorge almost wholly unmarred by man," but also "because the revenues to Kentucky would be greater annually than the cost of building the proposed power plant." Satisfied that he had convinced his audience of both of these points, Wallace encouraged the women "to ask the Federal Power Commission to save Cumberland Falls."

Although the speech stirred the Women's Club audience that night, the New York Times coverage of it a day later provided the wider media support that Wallace so desired. Under the headline "Kentucky Editor Seeks to Save Cumberland Falls from

\footnotetext{
${ }^{3}$ Wallace, "Address to the General Federation of Women's Clubs on the occasion of their John Burroughs Day Celebration, Wanamaker's Auditorium, New York City, 3 April 1926." Tom Wallace
} 
Going to Utility Concerns," the article stressed Wallace's indictment of the "commercializers" rather than his preservation arguments. It included quotes from Wallace, warning that "unless preventative measures be taken ... assets of incalculable value to the people will be swept into the coffers of corporations which function as power vendors and stock jobbers." ${ }^{4}$ By emphasizing Wallace's indictments of corporate greed instead of his preservation sentiment, the editors of the New York Times put a powerful spin on the speech, which brought the issue closer to home for more readers. From this early article, Wallace realized that, although he believed in preservation for its own sake, he could reach far more people if he put the proper spin on his protests. Over the course of the campaign, Wallace would cater his message to each audience in an attempt to maximize its effect, while remaining steadfast in his belief that action should be taken to protect the Falls from commercial encroachment.

A week later in an April 10, 1926 editorial published in The New York Times, Wallace refined this tactic. This time, he did not mince words. In his first sentence he declared the situation at Cumberland Falls "an impending catastrophe" in a state that lacked "adequate public sentiment to protect from destruction certain assets which should belong forever to Kentuckians and to the larger public." ${ }^{5}$ To Wallace, Cumberland Falls belonged to the people of Kentucky and not to private corporations like Insull's. Again, by contrasting the "unmarred" and "picturesque" scenic beauty of the Falls against the "avarice of exploiting corporations," Wallace believed he could convince the public that

\footnotetext{
Papers, FHS.

${ }^{4}$ New York Times, 4 April 1926.

${ }^{5}$ New York Times, 10 April 1926.
} 
they owned the Falls, and that greedy corporations wanted to take it from them for selfish reasons. $^{6}$

On another front, Wallace brought public attention to the complicated issue of the Federal Power Commission's jurisdiction over the Falls, which he viewed as tenuous at best. Legally, the Federal Power Commission had jurisdiction only over "navigable" waterways that could be deemed instruments of "interstate commerce." Although the Cumberland River was impossible to navigate in the vicinity of the Falls, the downstream waters could be considered navigable. Therefore, the FPC had the final authority to approve or deny construction projects affecting the entire waterway. Understandably, Wallace viewed this interpretation with suspicion. Later, however, when it appeared doubtful that the state legislature would protect the Falls, Wallace welcomed the Power Commission's jurisdiction because it provided the last line of defense against the dam. Although conservationists expected the Commission to rule on the Insull permit within sixty days of the Kentucky legislature's March 1926 decision, the commissioners chose instead to postpone the case indefinitely. Whether influenced by Wallace's efforts or other factors, the Commission's refusal to issue a ruling indicated unease on the part of its members towards the project. In the summer and fall of 1926, the issue receded somewhat from the public spotlight. ${ }^{7}$

Undeterred, Wallace continued to criss-cross the country speaking and writing on behalf of the Falls. In June 1926 he spoke to the National Conference of State Parks in

\footnotetext{
${ }^{6}$ Ibid., 10 April 1926.

${ }^{7}$ George W. Robinson, “Conservation in Kentucky: The Fight to Save Cumberland Falls, 19261931," Register of the Kentucky Historical Society, v. 81 no. 1 (Winter, 1983), 31; For a more thorough discussion of the FPC's jurisdiction see: Tom Wallace, "Saving Cumberland Falls," American Planning and Civic Annual, vol. 2, 1930, 141.
} 
Hot Springs, Arkansas, presenting colorful slides of the Falls. ${ }^{8}$ The following April, he gave an impassioned speech to the national convention of the Izaak Walton League in Chicago, urging league members to "bring to bear, resolutely, the great influence of the League" and "make it forever impossible for any selfish enterprise to make a mere power plant of Kentucky's major scenic asset." At the convention, the League unanimously passed a resolution in favor of saving the Falls, giving Wallace the official backing of one of the most influential conservation organizations in the country.

With the Izaak Walton League on board, Wallace then attracted the attention of one particularly prominent philanthropist whose individual support alone would change the complexion of the entire debate. Perhaps drawn into the controversy by the wave of publicity that Wallace was generating, Senator T. Coleman duPont of Delaware wrote to his friend Helm Bruce in Louisville on April 6, 1927 and offered to provide $\$ 200,000$ to purchase the Falls and the surrounding land and then to donate it to the state provided that the area be developed exclusively as a state park. ${ }^{10}$ A native of Kentucky, duPont had made a fortune in coal and later as a supplier of the majority of the nation's gunpowder, saltpeter, and dynamite. By the 1910s, duPont had built his family business into an empire and he used his considerable fortune to engage in philanthropy. Between 1911 and 1917 , duPont personally spent nearly $\$ 4$ million of his own money to construct a

\footnotetext{
${ }^{8}$ Wallace to Caufield and Shook Photographers, Louisville, Ky., 13 April 1927. Tom Wallace Papers, FHS.

${ }^{9}$ Wallace speech to the Izaak Walton League of America, 9 April 1927, at the Sherman Hotel, Chicago, Ill. Tom Wallace Papers, FHS. The Izaak Walton League was formed in 1922, largely by a group of Midwestern sportsmen to "defend the nation's soil, air, woods, and wildlife." The league was named after seventeenth-century Englishman and author of The Compleat Angler, a wildly successful book "about the pleasures and techniques of sport fishing." According to Philip Shabecoff, the League organized "the first modern environmental lobbying campaign in Washington" when it prevented the draining of large sections of the Upper Mississippi River during the Coolidge administration. See: Philip Shabecoff, $A$ Fierce Green Fire: The American Environmental Movement (Washington, D.C.: Island Press, 2003), 80.

${ }^{10}$ Robinson, "Conservation in Kentucky," 31.
} 
highway from Wilmington, Delaware to the Maryland border. Also a generous benefactor of the Republican party, duPont helped elect president Harding in 1920 and he became quite a fixture at the White House during the Harding administration. He also served two terms in the Senate from 1921 to 1928 , until he resigned amid investigations implicating him in the Teapot Dome Scandal. ${ }^{11}$

For duPont, the estimated $\$ 200,000$ sticker price for Cumberland Falls was merely a drop in the bucket, though for Wallace and other conservationists it provided incalculable leverage against state legislators who had previously rejected the eminent domain bill on the grounds that the State Park Commission lacked sufficient funds to purchase the Falls. With duPont providing the missing funds, all that was required of the state was to engineer a way for duPont to purchase the Falls tract legally and for the state to accept a donation of the land as a state park. That is, of course, if the Federal Power Commissioners continued to delay their decision in the matter and allow the Kentucky legislature another opportunity to pass protective legislation.

After learning of duPont's generous offer, Wallace took it upon himself to lubricate the political gears necessary for the Falls' preservation. At the same time that he was publicizing the Falls in the media, he began a potent behind the scenes lobbying campaign, beginning with Governor Fields and ending with the Federal Power Commissioners. Initially, duPont had requested that his offer remain anonymous, and in his correspondence Wallace did not identify him, speaking of him only as "the gentleman who proposes to buy Cumberland Falls" and "the prospective donor."12 From correspondence in early June of 1927, however, it is clear that Wallace had discovered

${ }^{11}$ Charles H. Mackay, Louisville Encyclopedia, 259; Kentucky Encyclopedia, 275. 
the donor's identity. That month he wrote to Stephen Mather asking for his company on a quick trip to Frankfort to visit Governor Fields and to discuss the duPont proposal. ${ }^{13}$ "The information I have is that the gentleman who would buy the Falls is willing to act at once," Wallace wrote, "and if so, it would be of great importance to close up the deal while Governor Fields is in office." 14

For some reason, Mather and Wallace were unable to make the trip before Wallace departed on July $11^{\text {th }}$ for an official two-month tour of Europe as part of the Carnegie Endowment for International Peace. Before his departure, however, Wallace phoned Governor Fields informing him of duPont's proposal, Mather's support, and the possibility that an option to buy the Falls property might be obtained from Mr. Brunson, owner of the land surrounding the Falls and manager of the Moonbow Inn there. In light of the information and at Wallace's request, Fields drafted a letter certifying that, if obtained by the state, the Cumberland Falls land would be developed only as a state park and nothing else. Wallace then presented the governor's letter, along with the information of the duPont offer, to the Federal Power Commission in the hope that they might be persuaded to refuse the permit or put off their decision until another state legislature considered the matter. ${ }^{15}$ Fortunately, the Commission stalled, deciding to postpone all consideration of the Falls case for the remainder of the year. ${ }^{16}$ By their decision to postpone the case, the Commission effectively chose to leave the controversy

${ }^{12}$ Wallace to Stephen Mather, 7 June 1927; to Governor William J. Fields, 7 July 1927; and to Charles W. Folds, president of the Izaak Walton League, 11 July 1927. Tom Wallace Papers, FHS.

${ }^{13}$ For some reason - perhaps out of pure humility--duPont did not want his name identified in any way with the park. See: Courier-Journal, 4 February 1930.

${ }_{14}^{14}$ Wallace to Mather, 7 June 1927. Tom Wallace Papers, FHS.

${ }^{15}$ Wallace to Governor William J. Fields, 7 July 1927. Tom Wallace Papers, FHS.

${ }^{16}$ Robinson, "Conservation in Kentucky," 31-32. 
in the hands of a new state administration after the upcoming November elections. For a moment conservationists caught their breath, but Wallace did not relent.

Frustrated that the Commission had not rejected the permit outright, Wallace took another course of action, one that was more familiar to him. In October 1927, he publicly broke the news of the duPont gift in an attempt to heighten national publicity for the Cumberland Falls case. Wallace knew of duPont's favorable reputation as a senator and philanthropist, and by attaching his name to the Cumberland Falls campaign, he sought to win additional converts to his cause. In an article first appearing in the Louisville-Times and later carried by several other dailies, Wallace revealed that he had obtained, on duPont's behalf, an option to purchase the Falls tract from Brunson provided that the Cumberland Hydro Electric Company did not exercise their similar option which expired on October 16. Wallace argued that if the public knew of duPont's selfless intentions to donate the Falls tract as a state park, then the power interests might be less inclined to exercise their option for fear that it would provoke widespread public disapproval. ${ }^{17}$ On top of that, the power company still had no indication from the Federal Power Comissioners whether or not their permit application would ever receive final approval. To bolster his case, Wallace wrote to several friends, both conservationists and journalists, and urged them to publish statements in support of preserving the Falls. In most instances, he even suggested a particular spin for the story. Writing to Ray Holland, editor of Field and Stream, Wallace noted that "it might be suitable for you to have an article on the duPont offer as evidence of the awakening of men of large wealth to the FHS.

\footnotetext{
${ }^{17}$ Wallace to Frank duPont, son of T. Coleman duPont, 11 October 1927. Tom Wallace Papers,
} 
value of gifts of conservation." ${ }^{\prime 18}$ On October 11, Wallace wrote similarly to his friend and former colleague Arthur Krock of the New York Times. Krock had been Henry Watterson's protégé at the Courier-Journal, but when Judge Bingham purchased the paper Krock was demoted. After serving briefly as editor of Bingham's evening paper, the Louisville Times, Krock departed for New York City in search of a more promising position. ${ }^{19}$ Despite his forced departure, Wallace considered Krock an old friend and he wrote to him suggesting that the New York Times publish "a small editorial speaking well of Senator duPont's proposed gift to his native state." 20

Likely due to his persistence, the New York Times ran a story on October 15, 1927, framing the Cumberland Falls case in light of a recent controversy surrounding the construction of a dam near Niagara Falls. The paper alleged that "Conservationists all over the land are united in an endeavor to prevent the same thing happening to the great falls of Cumberland." ${ }^{21}$ As he always did, Wallace wrote to Holland, Krock, and others thanking them for their media support in his publicity campaign. In addition, he requested from them copies of any articles they published in support of the Falls along with the right to reprint them if necessary. Thus, by compiling a personal archive of articles from several prominent publications, Wallace amassed a sizable publicity arsenal. As a result, he was able to augment the effectiveness of his own editorials by frequently and generously citing other prominent journalists and conservationists around the nation who publicly voiced their opposition to the dam.

\footnotetext{
${ }^{18}$ Wallace to Ray Holland, 11 October 1927. Tom Wallace Papers, FHS.

${ }^{19}$ Marie Brenner, House of Dreams: The Bingham Family of Louisville (New York: Random

${ }^{20}$ Wallace to Arthur Krock, 11 October 1927. Tom Wallace Papers, FHS.

${ }^{21}$ New York Times, 15 October 1927, 18.
} House, 1988), 91, 132. 
Throughout the 1920s and 1930s, Wallace along with other journalists turned conservationists like Jay N. "Ding" Darling, the Pulitzer prize winning cartoonist for the Des Moines Register, gained positions of prominence in the conservation movement due to their ability to coordinate effective propaganda campaigns. ${ }^{22}$ Although "the crusading spirit is as old as journalism," as Michael Emery writes, many journalists of the late nineteenth and early twentieth century traditionally attempted to cover stories like Cumberland Falls objectively. ${ }^{23}$ By the 1920s, however, stories became "more interpretive" and "the effort to propagate ideas" gained currency among many journalists. ${ }^{24}$ Of the importance of media support and news propaganda for conservation, Wallace later remarked: "A vigorous publicity campaign, in the press, if press support be available, . . will in many cases avert destructive encroachment. ${ }^{, 25}$

While Wallace's publicity efforts made inroads in national conservation circles, the political wrangling of the bitter election season overshadowed the Cumberland Falls controversy back in Kentucky. According to John Ed Pearce, Kentuckians at the turn of the century were "divided, backward, poor, and largely resentful of culture." 26 The atmosphere in 1927 was no different. During the Democratic primary in August intense

\footnotetext{
${ }^{22}$ Jay Norwood "Ding" Darling was a contemporary and close friend of Wallace. Most famous for his editorial advocacy of soil erosion, stream pollution, and other misuses of land and wildlife, Darling's rise to national prominence in the conservation movement most closely paralleled Wallace's. While Wallace used the written word, Darling used his pointed cartoons to publicize conservation topics from the 1920s and 1940s. In 1934 and 1935, Darling took a sabbatical from his editorial work to serve as chief of the Biological Survey, the forerunner to the Fish and Wildlife Service. He also organized and served as the first President of the National Wildlife Federation. See Henry Clepper, ed. Leaders of American Conservation (New York: The Ronald Press Company, 1971), 87-88.

${ }^{23}$ Michael Emery, Edwin Emery, and Nancy L. Roberts, The Press in America: An Interpretive History of the Mass Media, $9^{\text {th }}$ ed. (Boston: Allyn and Bacon, 2000), 213.

${ }^{24}$ Michael Schudson, The Power of News (Cambridge: Harvard University Press, 1995), 63; idem., Discovering the News: A Social History of American Newspapers (New York: Basic Books Inc., 1978), 135.

${ }^{25}$ Tom Wallace, “Conference Conclusions,” American Planning and Civic Annual (1955), 194.

${ }^{26}$ John Ed Pearce, Divide and Dissent: Kentucky Politics, 1930-1963 (Lexington, KY: University of Kentucky Press, 1987), 24.
} 
factionalism arose over the issue of pari-mutuel gambling at horse tracks in the state. As a result, a fissure opened in the Democratic party with anti-gambling advocate J.C.W. Beckham of Louisville receiving the party's nomination. Supporters of gambling in Louisville, including Democrats, threw their weight behind Republican candidate Flem Sampson of London, Kentucky. With the added support of the Louisville Democrats, Sampson won the November election by a sizable margin. ${ }^{27}$ Despite his success at the polls, "Sampson's term was not a happy one," according to Pearce. For reasons that would soon become apparent, he earned the unfortunate nickname "flim-flam-Flem.",28 After Sampson's inauguration in January, Wallace wasted no time apprising the governor of his position on the Falls. In a January 13, 1928 letter to Sampson, Wallace quoted statements by Senator Simeon Fess (Rep) of Ohio and Representative James H. Sinclair (Rep.) of North Dakota, both of whom publicly supported his preservation initiative. He also stated, matter-of-factly, that "practically every conservationist organization of any importance in the United States has protested to the Federal Power Commission against the commercialization of Cumberland Falls." ${ }^{29}$ In the same letter, Wallace lauded Sampson's short track record on conservation issues and he cleverly suggested to the governor that if the Falls were preserved under his watch, then he should get all the credit. ${ }^{30}$

Anxious to consolidate power, Sampson addressed the state legislature on January 19 and called for state acquisition of Cumberland Falls. ${ }^{31}$ Conservationists applauded

${ }^{27}$ Robert F. Sexton, “Flem D. Sampson,” in Lowell H. Harrison, ed., Kentucky's Governors (Lexington: University of Kentucky Press, 2004),160-163.

${ }^{28}$ Pearce, Divide and Dissent, 27-28.

${ }^{29}$ Wallace to Governor Flem Sampson, 13 January 1928. Tom Wallace Papers, FHS.

${ }^{30}$ Ibid., 13 January 1928.

${ }^{31}$ Courier-Journal, 20 January 1928. 
and had further cause for optimism when the governor issued a strong endorsement of a statewide fundraising campaign to acquire Mammoth Cave in the central part of the state. At Mammoth Cave, Sampson hoped to secure one of the few national parks east of the Mississippi River and thus capitalize on the upsurge in the park tourism industry. ${ }^{32}$ Encouraged by the governor's message, conservationists across the state praised Sampson. The state chapter of the Izaak Walton League even named him their honorary president for $1928 .^{33}$

With the governor on board, conservationists anticipated swift action at the next legislative session to condemn the Cumberland Falls property and approve the duPont gift. The scheduled meeting of the Southern Forestry Congress in Louisville on February 14 and 15 was expected to help matters, especially because Wallace served as president of the organization. ${ }^{34}$ With conservationists from across the South descending on Kentucky and lending their support in the fight, it seemed only a matter of time before the legislature introduced a bill to condemn the Falls tract and give the state authority to accept the duPont gift. Moreover, as long as the Power Commission delayed a final decision on the issue, the prospect of future hydroelectric development at the Falls remained an uncertainty. Wallace and other conservationists reasoned that the Insull interests were unlikely to exercise their option on the Falls without assurance that the Power Commission would grant the permit. For conservationists, it was imperative that the state legislature take swift action in the matter before the Power Commission acted.

\footnotetext{
${ }^{32}$ Robinson, "Conservation in Kentucky," 32.

${ }^{33}$ Ibid., 33.

${ }^{34}$ Wallace was elected President of the Southern Forestry Congress in 1927 and served in that capacity through 1928. His primary duties included publicizing the organization and organizing the group's annual meeting. See Tom Wallace Papers, 1927 correspondence, FHS.
} 
As expected, Senator James K. Waller of Union County introduced the second “eminent domain" bill in early February of $1928 .{ }^{35}$ Unlike the debates held two years earlier on the same issue, however, this time the hearings were to be open to the public. As historian George Robinson argues, conservationists would eventually relish the opportunity for public hearings "when the full force of an aroused public had been mobilized," but in 1928, public hearings favored the calculated arguments of a wellfunded and coordinated power lobby over protests made by disorganized and under funded conservationists. ${ }^{36}$

Nonetheless, as an experienced public speaker and debater, Wallace took advantage of his opportunity to stand before the public in opposition to the dam. As the hearing opened, Wallace made it clear that state legislators were improperly influenced by Insull lobbyists rather than their constituents in Kentucky. Quickly, pro-dam state senators E.L. Stephens, Ed Gatliff, and H.H. Tye denied the accusation. Tye, returning fire, suggested that Wallace and the Louisville newspapers had unfairly characterized public sentiment as against the dam when, according to Tye, most residents around the Falls favored the Insull plan. In addition, Tye charged Wallace and the Courier-Journal with "defaming the mountain people." 37 Tye claimed that pro-dam advocates represented the "plain folks" in Southeastern Kentucky, while Wallace and his fellow conservationists represented the "idle rich." Perhaps Wallace had misjudged the level of local support for the Falls, but he flatly denied defaming the mountain people and demanded that Tye cite a specific story and date. Tye could not. ${ }^{38}$

\footnotetext{
${ }^{35}$ Robinson, "Conservation in Kentucky,” 33.

${ }^{36}$ Ibid., 33.

${ }^{37}$ Courier-Journal, 24 February 1928.

${ }^{38}$ Ibid., 24 February 1928.
} 
As the hearing proceeded, Wallace proved his considerable skills as a debater, but being outnumbered by pro-dam advocates, the hearing quickly turned into a "melee," according to the Courier-Journal's coverage of the event. ${ }^{39}$ When the hearing ended, two factors were evident. Although local public sentiment was still bitterly divided on the issue, the majority of state legislators supported the dam. As a result, the house committee voted 4-2 to report the Waller condemnation bill unfavorably. A day later, the senate rejected the bill by a four-vote margin leaving open the possibility for the Insull interests to exercise their option on the Falls tract if the Federal Power Commission granted a permit. Curiously, the governor's input was absent from the entire hearing, raising Wallace's suspicion that he too had been somehow roped in by the power lobbyists. ${ }^{40}$ With the state legislature failing to protect the Falls, the locus of the dispute shifted back to the Federal Power Commission.

Frustrated by the state senate's decision, Wallace continued his appeals to conservation organizations and continued his publicity work in editorials. With his preservationist propaganda growing stale, Wallace needed a new spin on the controversy and less than a week after the state hearings ended, Governor Sampson provided one. Publicly declaring the last week in February "Mammoth Cave week," Sampson intensified his fundraising campaign for state acquisition of the cave. In an address delivered over WHAS radio, the state's most powerful station, Sampson described the cave as "a marvelous gift of God to Kentucky" that was "too little appreciated, too little

${ }^{39}$ Ibid.

${ }^{40}$ In 1 and 2 February 1928 correspondence with U.S. Representative W.V. Gregory, Wallace expressed doubts that the Governor would uphold his promise to acquire Cumberland Falls. He writes, "I am not confident that Governor Sampson is going to stand to the guns," and "I am afraid Governor Sampson is going to turn us down." Tom Wallace Papers, FHS. 
talked by our own people, and too little frequented by others."41 Speaking broadly of Kentucky's scenery, the governor added: “One of the most striking of Kentucky's assets is the varied and abundant charm of her out-of-doors," which he identified as "fields and streams, mountain crests, and cataracts." ${ }^{42}$ Together, the governor exclaimed "the beauty, picturesqueness, and richness of Kentucky will sell her to the world once she is seen."43

Not surprisingly, Wallace was shocked by Sampson's demonstrated zeal for the Mammoth Cave project and his silence on Cumberland Falls. In Wallace's view, these were two obviously connected issues. Stephen Mather joined Wallace in expressing his disbelief. ${ }^{44}$ How could Sampson enthusiastically support a project that would cost the state hundreds of thousands of dollars while remaining silent on Cumberland Falls, which as a result of duPont's offer, would not cost the state a penny? Moreover, why did the governor, in his radio address, carefully exclude the Cumberland cataract from his longwinded ode to Kentucky's scenic beauty? Wallace correctly sensed that something was awry and he capitalized on the governor's inconsistency to suggest that Sampson had conspired with power lobbyists to support the dam. By late April 1928, Wallace had confidential information to confirm his suspicion. Not only had Sampson refused to support the Waller condemnation bill at the state hearing, but also according to Wallace's sources, he was now scheduled to appear before the Power Commission at their next hearing on behalf of the power interests. ${ }^{45}$

\footnotetext{
${ }^{41}$ Courier-Journal, 28 February 1928.

42 Ibid., 28 February 1928.

${ }^{43}$ Ibid., 28 February 1928.

${ }^{44}$ As quoted in Malcolm Bayley, "Kentucky Stirred by Power Project," New York Times, 20 May $1928,47$.

${ }^{45}$ Wallace to W.F. Martin, secretary to Senator T. Coleman duPont, 27 April 1928. Tom Wallace Papers, FHS. Although Wallace confirms the accuracy of the information, he does not reveal his sources.
} 
In an effort to save face for the governor, who had so quickly reversed his opinion of the dam project, state representatives in the predominantly Republican Eleventh District near the Falls quickly orchestrated a resolution calling upon the governor to urge the Commission to issue the power permit. ${ }^{46}$ With the resolution, the representatives reasoned, it would appear that local public sentiment in Kentucky had democratically influenced the governor to switch his position rather than his clandestine negotiations with Insull lobbyists. Thus, the orchestrated resolution served two purposes simultaneously. On one hand it gave the impression that elected officials in the Falls region were responsive to the desires of "ordinary" folks who supported the dam. On the other, it gave the governor a convenient opportunity to cover up his secret negotiations with Insull representatives. To Wallace, however, the political machinations behind the resolution only served to confirm his long held belief that "in Kentucky the scenery is the grandest — and politics — the damnedest. ${ }^{, 47}$

Fortunately, for Wallace's sake, people outside of Kentucky started to question the extent of the corruption in the power industry at precisely the same time that the Cumberland Falls issue was gaining national attention. This shifting sentiment provided Wallace with ample fodder for a new line of argument on behalf of the Falls. Progressive senators like Thomas Walsh of Montana and George Norris of Nebraska were openly criticizing the private power trusts, and in January 1928, Walsh introduced a resolution calling for the formation of a special senate committee to investigate the entire utilities industry. Senator Norris backed the resolution and suggested that immediate

He describes the sources to Martin as "the friends with whom I had the pleasure of calling upon you last week." It is uncertain who those "friends" were.

${ }^{46}$ Malcolm Bayley, New York Times, 20 May 1928.

${ }^{47}$ James H. Mulligan, "In Kentucky," from a postcard, FHS. 
action be taken to combat "a trust of gigantic proportions which controls the generation and distribution of electricity by water, power, and other means."48 Although not a conservationist by any standard, Norris had observed the potential danger of enormous private power trusts in the Muscle Shoals fiasco, where high paid lobbyists for private power companies had persistently fought to keep the supposedly public project under private control. As a progressive, Norris fought for state control over the utility industry. $^{49}$

In a January $15^{\text {th }}$ New York Times editorial, Norris painted a vivid picture of the vast power trust in America. He described a clever scheme involving multiple layers of ownership that enabled large power companies to disguise their abusive transactions. He also noted the huge sums of money that private utility companies spent on propaganda and influencing elections. In classic progressive rhetoric, Norris argued that government should regulate and, if necessary, assume control of some utilities because "after all, the rivers and other natural sources of this vast national asset belong to the people." Although he argued primarily as a progressive and not as a conservationist, Norris nevertheless served Wallace and other conservation interests in Kentucky by casting a shadow of suspicion on the entire private utility industry, which included the Insull empire. At Norris's suggestion, the U.S. Senate began, under the auspices of the Federal Trade Commission, a highly publicized investigation into the entire utility industry in early 1928 that continued throughout the remainder of the controversy. In a letter to Wallace, Gifford Pinchot, the "father of conservation," speculated that "this matter of

${ }^{48}$ George W. Norris, as quoted in "Power Industry Faces an Inquiry in Senate," New York Times, 15 January 1928, 130.

${ }^{49}$ Ibid., 15 January 1928.

${ }^{50}$ Ibid., 15 January 1928. 
power ... is going to be the next big issue in Washington in the next few years." ${ }^{, 51}$ Citing his feelings on the issue, Pinchot wrote, "this utility crowd have certainly been playing a rotten game." 52 Thus, due to the increased publicity and growing public suspicion of Insull and other power magnates brought about by the investigation, Wallace and other conservationists now had a convenient way to discredit the Insull dam project before a much more sympathetic audience in Kentucky.

In an effort to link the Cumberland Falls case directly to the growing distrust of the private utility industry, Wallace wrote to Senator duPont in May and suggested that he talk to Senator Norris about considering the Cumberland Falls case specifically as part of the Senate's investigation. ${ }^{53}$ According to a 1930 study, the Insull utilities empire consisted of some 111 subsidiary companies and controlled production of roughly a tenth of the nation's electricity. For Wallace, Insull and his subsidiary, the Cumberland River Power Corporation, were ideal targets for Norris's investigation. As duPont informed him, however, Senator Norris "did not see how he could logically make this situation a part of his power question." ${ }^{, 54}$ Instead, Norris suggested passage of a joint resolution in congress requesting that the Power Commission delay action in the matter until the state legislature could hear the case again. Yet again, it appeared as if the case might be remanded to the state legislature. DuPont enlisted the help of Senator and future vice-

${ }^{51}$ Gifford Pinchot to Wallace, 10 November 1928. Tom Wallace Papers, FHS. Pinchot served as Chief of the United States Forestry Service from 1898 to 1910. He founded the School of Forestry at Yale University in 1900 and organized and served as president of the National Conservation Association. Pinchot also served two terms as Governor of Pennsylvania from 1923 to 1927 and from 1931 to 1935. See: Henry Clepper, ed., Leaders of American Conservation), 259-260.

${ }_{53}^{52}$ Pinchot to Wallace, 19 November 1928. Tom Wallace Papers, FHS.

${ }^{53}$ Wallace to Warren F. Martin, Secretary to T. Coleman duPont, 11 May 1928. Tom Wallace Papers, FHS.

${ }^{54}$ Martin to Wallace, 15 May 1928. Tom Wallace Papers, FHS. 
president Alben Barkley in bringing the resolution, but the legislative session ended before it could be introduced. ${ }^{55}$

Despite their inability to secure the resolution and the potential threat of a final decision by the Federal Power Commission, Wallace and other conservationists began to sense that in some small ways the atmosphere surrounding the case had shifted in their favor. While there were still immense political hurdles to overcome both in Kentucky and on a national scale, the growing public distrust of the private utility industry clearly aided conservationists. As an opportunist keenly aware of this situation, Wallace jumped on the chance to link preservation of Cumberland Falls with suspicion of the Insull interests. At the same time, he continued to demonstrate as he had all along, that even without the economic boon of a dam project the park could still generate a handsome profit. Due to a series of unexpected events, however, the battle was about to get much more complicated.

\footnotetext{
${ }^{55}$ Ibid., 15 May 1928.
} 


\section{CHAPTER III}

\section{“CAUGHT IN THE POWER NET”: CUMBERLAND FALLS ENTERS THE NATIONAL SPOTLIGHT}

As the Cumberland Falls case loomed before the Federal Power Commission during the latter part of 1928 and much of 1929 it became increasingly a matter of national political significance for a number of reasons. First, the Senate was already engaged in an investigation of the private utility industry. Second, there was a presidential campaign slated for November. Together, these factors contributed to an atmosphere in which Cumberland Falls became a buzzword for much more than conservation. It became the focus for debates over the jurisdictional limits of the Federal Power Commission, the extent of corruption in Kentucky politics, and the value of scenic attractions generally. For some conservationists like Wallace, however, this politicization of Cumberland Falls was a welcome shift. As a political issue, Wallace could attract a wider audience to his cause. As this chapter demonstrates, Wallace responded to developments in 1928 and 1929 by refining his arguments and winning new converts to his preservation campaign.

Along with Wallace's efforts, another important group emerged in March of 1928 to lobby for protective legislation for the Falls - the Cumberland Falls Preservation Association (CFPA). Angered by the lack of coordinated local effort in the case, some 
citizens in and around Corbin, Kentucky formed the CFPA in March of 1928 with the sole purpose of demonstrating that, contrary to the Insull propaganda, many residents nearby the Falls supported the duPont proposal. The CFPA included members of the Kiwanis Club, like T.W. Gallagher, and others like Reverend C.E. Vogel of Corbin, who served as the organization's president. ${ }^{1}$

When Secretary of the Interior and Chairman of the Federal Power Commission Herbert Work passed through Corbin in early June en route to visiting several western parks and Indian reservations, members of the CFPA sequestered him and pleaded their case for the Falls. Just a day earlier, though, Work had visited Middlesboro, Kentucky where pro-dam advocates had cornered him and described the area as a wasteland infested with "black snakes" and "seed ticks." Listening to these conflicting representations, it is uncertain what impression Work gleaned during his short visit to Kentucky, but ultimately it mattered little because he resigned from the Power Commission only three weeks later to chair the Republican National Committee. By late summer of 1928, then, conservationists remained uncertain how or even if the Federal Power Commission would decide the case. "I cannot advise whether the Power Commission will act before the election," Stephen Mather wrote to Wallace, "although I do not think it probable."”

In August, however, when President Coolidge announced his nomination of Roy O. West for Secretary of the Interior to fill the spot vacated by Work, conservationists had cause for concern. Even though West would only serve the remaining few months of

\footnotetext{
${ }^{1}$ Robinson, "Conservation in Kentucky: The Fight to Save Cumberland Falls, 1926-1931," Register of the Kentucky Historical Society, v. 81 no. 1 (Winter, 1983), 36.

${ }^{2}$ Courier-Journal, May 31, 1928 and June 1, 1928.
} 
Coolidge's administration, he was a proven enemy of conservation. It was common knowledge that West not only supported business interests overwhelmingly, but that he had previously served as counsel to utility interests controlled by Insull. ${ }^{4}$ In Wallace's view, Coolidge's nomination of West was an obvious attempt to remove the bureaucratic obstacles to the Insull plan. In fact, Wallace suggested that Coolidge had appointed West specifically to approve the Cumberland Falls project, saying "The decencies of this situation may be easily observed by President Coolidge who, if he did not have the Insull project in mind when he appointed West, could have held up these decisions until after the election." ${ }^{5}$ With West's confirmation imminent, conservationists nationwide launched into protest. To head off the impending tragedy, Wallace looked to presidential candidate Herbert Hoover, a proven friend of conservation. According to Wallace, Hoover had agreed the previous year in a private conversation to "speak to the Federal Power Commissioners about Cumberland Falls." If asked again, Wallace told Stephen Mather, "I believe he will do it."7

Meanwhile, while conservationists across the nation publicly challenged West's appointment, Wallace lamented the political situation in Kentucky. "Kentucky seems to be doing nothing for the Falls," Wallace argued, because the state "is at present misrepresented by a governor who represents the state in just about the sense as Mr. Coolidge's appointee as Secretary of the Interior represents the people." ${ }^{\prime 8}$ In addition to poor leadership in the state, the Cumberland Falls Preservation Association of Corbin

\footnotetext{
${ }^{3}$ Mather to Wallace, 23 August 1928. Tom Wallace Papers, The Filson Historical Society (FHS), Louisville, Ky.

${ }^{4}$ Robinson, "Conservation in Kentucky," 38.

${ }^{5}$ Wallace to Mather, 25 August 1928. Tom Wallace Papers, FHS.

${ }^{6}$ Ibid.

${ }^{7}$ Ibid.

${ }^{8}$ Wallace to Mather, 30 August 1928. Tom Wallace Papers, FHS.
} 
was also in a poor financial state, which would force it to suspend activities if additional funding was not secured. Wallace appealed to Senator T. Coleman duPont for support, but he concluded ultimately that accepting funds from the Senator for a private organization like the CFPC would be improper. ${ }^{9}$ Thus, with the Sampson administration refusing to endorse the duPont proposal and with local conservation organizations faltering, Wallace could only hope that perhaps Hoover or someone else could convince the Federal Power Commission to put off a decision until after the presidential election. If Hoover won the election, Wallace felt certain that he would spare the Falls. ${ }^{10}$

When Wallace received a copy of a letter from Secretary West stating that the Federal Power Commission would hold a public hearing "in the near future," he immediately feared the worst. ${ }^{11}$ He knew that the members of President Coolidge's Power Commission could not be counted on to side with conservationists over business interests. Indeed, Coolidge's entire cabinet had consistently opposed regulation of the private sector. Coolidge himself famously remarked that "the chief business of the American people is business." "12 If Coolidge's business friendly Power Commission ruled on the case, Wallace predicted a sequel to the Teapot Dome affair, the details of which were only then coming to light in 1928. As a congressional investigation revealed, President Harding's Secretary of the Interior Albert Fall had handed over huge sections of public oil reserves in Wyoming to private interests in 1922. In exchange, Fall received some $\$ 400,000$ in "gifts." In the shadow of the Teapot Dome controversy, Wallace wrote

\footnotetext{
${ }^{9}$ Wallace to Warren F. Martin, Secretary to T. Coleman duPont, 31 August 1928. Tom Wallace Papers, FHS.

${ }^{10}$ Wallace to Mather, 30 August 1928. Tom Wallace Papers, FHS.

${ }^{11}$ Ray O. West to Will L. Krietstein, President of the Tippecanoe River Riparian Owners Association, 20 September 1928. Tom Wallace Papers, FHS.

${ }^{12}$ George Tindall and David Shi, America: A Narrative History, $5^{\text {th }}$ ed. (New York: W.W. Norton and Co., 2000), 925.
} 
to a friend describing his plan to "bring enough pressure to bear upon them [the Power Commission] ... to keep them from donating Cumberland Falls to the power hogs under the same circumstances that Fall gave Elk Hills and Teapot Dome to his friends." ${ }^{13}$ If he could capitalize on the negative publicity surrounding the Teapot Dome scandal, Wallace reasoned, then perhaps he could avert a similar disaster at Cumberland Falls. As editor of Outdoor America, Marguerite Ives suggested to Wallace, "in the meantime, we can only weep and curse and pray." 14

As the December $5^{\text {th }}$ hearing loomed, discouraging news surfaced from within the Power Commission. In late October, Wallace learned that, despite protests leveled by conservationists, Executive Secretary C.C. Merrill had issued a recommendation to the Commission suggesting a possible solution to the dispute whereby the Insull interests could construct the hydroelectric dam but provide for a minimum water flow over the Falls "not more than one hundred cubic feet per second" to be determined by the State Park Commission or some other state authority. ${ }^{15}$ If the company consented to the arrangement, the Power Commission would most likely grant the permit. The resolution infuriated Wallace. He argued that under these terms "the Falls could be reduced to a pint a week if the State Park Commission should agree to it." ${ }^{, 16}$ As a result, he concluded that "all talk of the Falls being maintained by the Power Company is sheer dishonest propaganda." ${ }^{17}$ Nevertheless, as the Courier-Journal explained, Merrill's recommendations were "as a rule, perfunctorily approved by the Commission." 18

\footnotetext{
${ }^{13}$ Wallace to Mr. Holmes, 10 December 1927. Tom Wallace Papers, FHS.

${ }^{14}$ Marguerite Ives to Wallace, 6 September 1928. Tom Wallace Papers, FHS.

${ }^{15}$ Wallace to J. Sherman Porter of the Lexington Automobile Club, 31 October 1928. Tom Wallace Papers, FHS.

${ }^{16}$ Ibid.

${ }^{17}$ Ibid.

18 "Economic Expert Hits Insull Design on Kentucky Falls," Courier-Journal, 5 December 1928.
} 
Therefore, with Secretary Merrill supporting the dam, Ray West's appointment pending, and Governor Sampson heading the State Park Commission, the deck was overwhelmingly stacked in the power company's favor heading into the December hearings.

By that time, West had been confirmed and joined the Commission, despite conservationists' arguments that, because of his prior employment by Insull, his participation in the case clearly represented a conflict of interest. Accompanying West on the commission were Secretary of Agriculture William Jardine, Secretary of War Dwight Davis, and Executive Secretary O.C. Merrill. Together, they entertained arguments from conservationists, Insull representatives, and a number of Kentucky politicians including Governor Sampson.

During his allotted time, Sampson publicly endorsed the dam for the first time. Although conservationists suspected his leanings, Sampson announced that two months prior on October 8 he had entered into a friendly contract with the power company. According to the Courier-Journal, news of the Sampson contract "developed for the first time, in unexpected fashion." ${ }^{, 19}$ The revelation startled conservationists. They had suspected all along that the Governor supported the dam, but none could believe that he had signed a formal contract. Under the terms of the contract, Sampson, as acting head of the Kentucky State Park Commission, agreed to endorse the company's application for a permit in exchange for $\$ 250,000$ to be used for establishing a park near the Falls, building roads, and constructing bridges in the area. Before signing the contract, Sampson claimed that he had met with representatives for duPont and suggested that they reach a compromise to allow a dam at the site but use duPont's money to fund 
development of a state park nearby the Falls. With duPont declining to cooperate with his plan, Sampson argued that he had been forced to sign the contract, because it provided the only viable solution for both industrial development and park development at the Falls. ${ }^{20}$ "No man places a higher value on the beauty of the Falls than I do," Sampson claimed, "but there are obligations I owe my state that surpass scenic beauty." 21 According to the governor, these obligations included better schools, roads, and jobs for the Commonwealth that only the dam could provide. ${ }^{22}$

Sampson attributed his apparent reversal on the issue to his "Kentucky Progress Campaign," a new policy initiative to bring economic growth to the state. Throughout the hearing, though, Sampson insisted that the beauty of the Falls would not be destroyed. He reiterated the power company's plan to provide a minimum water flow over the Falls and he insisted that the surrounding area would be maintained in its natural condition. Countering Sampson, conservationists argued that the dramatic reduction in water flow would essentially ruin the waterfall even if the surrounding area remained untouched. As economist Basil Manly noted, "the only difference between a precipice and a waterfall is the presence of a river. And that is what ceases to exist as soon as the Insull dam is erected."23

As the hearing progressed, tempers flared on both sides. With two thirds of the time allocated to pro-dam interests, Republican Congressman John Robsion of Kentucky and Judge B.J. Bethurum of Pulaski County lashed out at conservationists. Bethurum

19 "Falls Probe Bares Pact By Sampson," Courier-Journal, 6 December 1928, 1.

${ }^{20}$ Robinson, "Conservation in Kentucky," 39.

21 "Falls Probe Bares Pact by Sampson," Courier-Journal, 6 December 1928, 2.

${ }^{22}$ Ibid., 6 December 1928.

23 "Economic Expert Hits Insull Design on Kentucky Falls," Courier-Journal, 6 December 1928, 2. 
argued that "scenic beauty won't add a single nickel" to the state's coffers. ${ }^{24}$ Robsion followed by charging the Courier-Journal with always ignoring the "wishes of mountain people." ${ }^{, 5}$ Striking back in the little time allotted to conservationists, Wallace questioned the power company's lobbying techniques. He rhetorically asked Insull attorney Robert G. Gordon if it was true that a representative from the Insull companies had been indicted and fined for unethical lobbying shortly after the Kentucky Legislature had voted against the 1926 bill to preserve the Falls. Interrupting Gordon's labored attempt at a response, Wallace demanded "you need only answer yes or no." ${ }^{, 26}$ Joining Wallace in protest against the Sampson-Insull contract were a number of prominent conservationists whom he had encouraged to appear at the hearing. They included Acting Park Service Director Arno Cammerer, former Governor William J. Fields, and representatives from the National Conference on State Parks, the American Civic Association, the Izaak Walton League, and the Camp Fire Club. ${ }^{27}$

Although pro-dam arguments monopolized the allotted time at the hearing, Wallace certainly won the battle for media coverage. The Courier-Journal's coverage of the event clearly indicated the paper's stance on the issue. The Courier began by describing the location of the hearings in the Secretary of the Interior's office as 'that high vaulted room where Albert B. Fall bargained away the naval oil reserves. ${ }^{28}$ Such a comparison was not lost on Kentucky readers, who, as a result of Wallace's constant media pressure, gradually began to question the impropriety of the governor's contract with Insull.

\footnotetext{
${ }^{24}$ Courier-Journal, 7 December 1928, 2.

${ }^{25}$ Ibid., 2.

${ }^{26}$ Ibid., 2.

${ }^{27}$ Ibid., 2.
} 
Fortunately for conservationists, the Power Commission did not rule on the day of the hearings. Instead, they encouraged conservationists and dam supporters to file formal briefs for consideration. While officials for both sides drafted briefs, many attorneys called into question the legality of the Sampson contract. Elsewhere, congressmen began to express more interest in the case. Senator Norris, long an opponent of the power trusts, inserted into the Congressional Record a series of articles by Basil Manly in opposition to the dam. Likewise, as the Courier-Journal pointed out, every member of Kentucky's congressional delegation had voiced their opposition to the dam except for Republicans John Robsion of Bracken County and Katherine Langley of Pikeville. ${ }^{29}$

When the hearings closed, Wallace wrote to his allies encouraging them to speak out against the contract, which he described alternately as "a very plain case of deliberate flim flam" and "little less than a bribe." 30 Putting his preservation philosophy aside, Wallace attacked the pro-dam interests for their unethical tactics and utter disregard for proper political procedure. He also appealed to Senators George Norris and Gerald Nye, questioning the ethics behind West's nomination and the propriety of his participation in the hearing. Sympathizing with Wallace, Nye noted that "out of the thousands of citizens available for appointment to the office of Secretary of the Interior, it ought to be possible to find at least one whose interests were quite wholly removed from the utility people."’1 Acting on this belief, Nye introduced a resolution in the Senate demanding that the Power Commission turn over all records regarding West's nomination and involvement in the Cumberland Falls affair. Despite Nye's resolution, West served the remaining months of

28 "Sampson Pact with Insull Hit," Courier-Journal, 7 December 1928, 3.

${ }^{29}$ Ibid., 3

${ }^{30}$ Wallace to Joseph Pulitzer of the St. Louis Post-Dispatch, 11 December 1928; and to Senator Thomas J. Walsh, 12 December 1928. Tom Wallace Papers, FHS. 
his term before the Hoover administration took over in March. Because of the controversy surrounding his appointment, however, West did state that, although he had been present at the Cumberland Falls hearing on December $5^{\text {th }}$ and at subsequent discussions about the case, he would recuse himself from voting on the issue. West's decision was a small victory for conservationists and especially Wallace who had brought considerable media pressure to bear on the issue. Without West's vote, the commission likely would be deadlocked, as most experts assumed that Secretary Davis and Secretary Jardine were divided on the case. ${ }^{32}$

In the meantime, attorneys for both sides submitted briefs to the Commission. Representatives of the American Civic Association (ACA) filed the first brief, which described the Sampson-Insull contract as "a highly improper attempt to influence a public judicial body." ${ }^{33}$ The brief alleged that there were several other logical sites where power could be developed instead of the Falls and that the agreement by the company to release a specific amount of water over the Falls was "not practical or really enforceable."34 Several other organizations filed briefs after the ACA. By and large, their arguments centered on the reduced water flow over the Falls under the terms of the contract. Conservationists also alleged that, according to their calculations of the contract, 97 to 99 percent of the water flow would be diverted for power use, effectively reducing the Falls to a trickle. In addition, Governor Fields claimed that roughly 95 percent of Kentuckians supported preservation of the Falls, a dubious but persuasive assertion. ${ }^{35}$

\footnotetext{
${ }^{31}$ Senator Gerald P. Nye to Wallace, 28 December 1928. Tom Wallace Papers, FHS.

${ }^{32}$ New York Times, 27 January 1929.

${ }^{33}$ Robinson, "Conservation in Kentucky," 41

${ }^{34}$ Ibid., 41.

35 “Falls Probe Bares Sampson Contract," Courier-Journal, 6 December 1928, 2.
} 
Pro-dammers, however, were quick to refute such claims. In a brief filed in January on behalf of the Cumberland Hydroelectric Company, attorney Robert G. Gordon argued that most Kentuckians had no opinion of the project. Although it is difficult to gauge the level of public support for the project, the news media in Kentucky and elsewhere overwhelmingly endorsed Wallace's position. Regardless, Gordon also challenged the 97 to 99 percent water flow reduction figures and instead claimed that only 52 percent of the water would be diverted for power purposes under normal conditions. ${ }^{36}$ For the first time, though, Gordon injected a new legal argument into the dispute. He claimed that the Power Commission had no authority to consider scenic beauty as a factor in reviewing the Insull permit application. According to Gordon, "scenic beauty" was too subjective and if the Commission accepted it as a standard, they could logically block any type of development in any place at any time. Instead, as the New York Times reported, Gordon argued that the Commission, under the terms of its mandate, "must base its decision solely on questions of river navigation and interstate commerce. ${ }^{37}$ From all accounts, Gordon's argument carried considerable weight. Indeed, the Commission only assumed jurisdiction over the Falls in the first place because the Cumberland River was deemed to be "navigable" some distance below the Falls. As long as the dam did not adversely affect the navigability of the stream, Gordon argued, the Commission had no right to turn down the company's application for a license.

In some ways, Wallace had anticipated the implications of Gordon's legal argument. Aware of the limitations of preservationist doctrine and "scenic beauty"

\footnotetext{
36 "Insull Brief Filed in Kentucky Case,” Courier-Journal, 27 January 1929.

${ }^{37}$ Ibid., 27 January 1929.
} 
arguments during the Coolidge administration, Wallace had argued all along that conservationists needed to develop stronger economic arguments in order to protect the Falls. Just a month before Gordon filed his brief in January, Wallace wrote to A.B. Guthrie of the Lexington Herald-Leader clarifying a statement he had made regarding the primary importance of economic arguments. He wrote:

In talking to you over the phone I may have given you the idea that the aesthetic value of Cumberland Falls does not interest me. What I meant was that for argument to be effective in Kentucky because of our low state of development it should never overlook the importance of tourist revenue, and that regardless of its aesthetic value, Cumberland Falls should be saved for its money producing capacity as a state park. ${ }^{38}$

Now, in light of Gordon's persuasive argument, conservationists began to realize that "scenic beauty" alone could not save the Falls. If the Power Commission had no authority to consider "scenic beauty" in its decisions, conservationists reasoned, then preservation of the nation's scenic waterways could never be accomplished through government channels. Accordingly, after January 1929 conservationists across the country began to pay special attention to the Commission's handling of the Cumberland Falls. Not only were they galvanized by their mutual disgust for Roy O. West's lastminute appointment and his connection to Insull, but now they feared a potentially devastating precedent for the entire preservation movement if the Power Commission refused to consider the value of scenery in weighing their decision. To address these developments, conservationists decided to shift the focus of their campaign from promoting the beauty of the park to contrasting the impropriety of the Sampson-Insull

\footnotetext{
${ }^{38}$ Wallace to A.B. Guthrie of the Lexington Herald-Leader, 22 December 1928. Tom Wallace Papers, FHS.
} 
contract with the selfless motives of duPont. At the same time, they continued to insist that a state park at the Falls would be more profitable to Kentucky than a power dam. ${ }^{39}$

Although the Commission did meet in January to discuss the briefs, Secretary West kept his word and refrained from voting on the case, likely due to the widespread opposition that had surfaced during his appointment hearings. Despite Gordon's convincing legal argument, West's absence from the Commission left the three-man body paralyzed, as conservationists had hoped. Incapable of reaching a verdict, the Commission passed the case to Hoover's new appointees after his March 4 inauguration. $^{40}$

As a new president entered the White House, conservationists breathed a sigh of relief. They had reason to be optimistic given Hoover's prior track record on conservation. An avid fisherman and outdoorsman, Hoover had been an ally and member of the Izaak Walton League, often contributing to the organization's magazine Outdoor America, the most widely circulated conservation publication in the country. As Secretary of Commerce, Hoover had lent his support to Izaak Walton League President Will Dilg's 1924 campaign to prevent the drainage of large sections of the upper Mississippi River. ${ }^{41}$ As Wallace revealed, Hoover had also promised in a private conversation in July 1927 to use his influence to preserve the Falls. ${ }^{42}$ From the outset, it appeared that conservationists had an ally in Hoover.

\footnotetext{
${ }^{39}$ Robinson, "Conservation in Kentucky," 41.

${ }^{40}$ Ibid., 41; Courier-Journal, 1 March 1929.

${ }^{41}$ Stephen Fox, John Muir and His Legacy: The American Conservation Movement (Boston: Little, Brown and Company, 1981), 168-169.

${ }^{42}$ Wallace to William Waller-Hawkins, General Manager of the Scripps-Howard Alliance, 2 March 1929. Tom Wallace Papers, FHS.
} 
When Hoover announced his cabinet appointments, conservationists had added cause to rejoice. Hoover's Secretary of War James Good would serve as the new chairman of the Power Commission and even though he had worked for power interests in the past, conservationists felt he would be fair. Hoover's other appointments to the Commission, Secretary of the Interior Lyman Wilbur and Secretary of Agriculture Arthur Hyde, were received with even more enthusiasm. Wilbur, formerly the president of Stanford, "had fame as a conservationist before he was a cabinet member" according to the Courier-Journal. Likewise, Hyde was a well-known outdoorsman in his home state of Missouri. $^{43}$

Although the Louisville Times had endorsed Governor Alfred Smith of New York over Herbert Hoover during the 1928 Presidential campaign, Wallace still welcomed the new president in March. As one "appreciative" of Hoover's "ability and integrity," Wallace believed that, if informed of the Falls situation, Hoover might "solve the problem by simple means." ${ }^{\text {44 }}$ Accordingly, he wrote to one of Hoover's closest political allies, Senator William Borah of Idaho, suggesting that he discuss the case with Hoover and persuade him to speak directly to the Federal Power Commission about the situation. Borah wrote back to Wallace, "I shall make it my business to talk to the President about the matter . . a at the very first opportunity." ${ }^{, 45}$ Whether Borah followed up on his promise is uncertain, but Wallace held out hope that Hoover might "influence the Federal Power Commission to do the right thing. ${ }^{246}$ He still noted, however, that the legal issues raised

\footnotetext{
${ }^{43}$ Courier-Journal, 11 October 1929.

${ }^{44}$ Wallace to Senator William Borah, 2 March 1929. Tom Wallace Papers, FHS.

${ }^{45}$ William Borah to Wallace, 5 March 1929. Tom Wallace Papers, FHS.

${ }^{46}$ Wallace to Borah, 2 March 1929. Tom Wallace Papers, FHS.
} 
by Gordon's brief made the Cumberland Falls case "immensely more interesting than it could be otherwise. ${ }^{47}$

As interest in the case spread rapidly among various conservation organizations, many invited Wallace to speak on behalf of the Falls. In early April, Wallace spoke to over 3,000 members of the New York Federation of Women's Clubs during their annual celebration of Conservation Week. Using color slides of the Falls, he urged the Federation to speak out on behalf of both Cumberland Falls and the Great Falls of the Potomac, which were also being threatened with development. In addition to the 3,000 members present at the meeting, the New York Times' coverage of the event reached an even broader audience. ${ }^{48}$ Wallace later confessed that his use of slides had been so effective that he considered having a film made on the subject. ${ }^{49}$ Later that April, he spoke at the Izaak Walton League's national convention in Chicago, which had recently named Hoover its honorary national president. A few weeks later, he addressed the National Conference on State Parks in Cleveland. ${ }^{50}$

At every opportunity, Wallace promoted the Falls. To preservation minded conservationists, like the members of the Women's Clubs, Wallace highlighted the scenic beauty and natural splendor of the Falls. To groups who promoted the recreational value of parks, like the National Conference of State Parks, Wallace emphasized the economic benefits of tourism at the Falls. Wherever he went, he molded his message to his audience, a skill he had practiced both as a journalist and as a guest lecturer on a variety of topics, from local history to zoology to foreign travel. At every speaking engagement,

\footnotetext{
${ }^{47}$ Wallace to William Waller-Hawkins, 2 March 1929. Tom Wallace Papers, FHS.

${ }^{48}$ New York Times, 4 April 1929.

${ }^{49}$ Wallace to Seth Gordon, President of the Izaak Walton League, 8 April 1929. Tom Wallace Papers, FHS.
} 
Wallace would also invite the audience to accompany him to the Falls and to see for themselves why they should be preserved. By May 1929, both Herbert Evison, President of the National Conference of State Parks, and Seth Gordon, President of the Izaak Walton League, had agreed to make the trip. ${ }^{51}$

With Wallace generating attention in the conservation community, newspapers and magazines across the country began to report on the Falls case with more frequency. Publicity reached its peak, though, in July of 1929 when Survey Graphic magazine carried as its cover story an article by Wallace titled "Caught in the Power Net." According to historian George Robinson, Wallace's eight-page article on the Falls controversy was "perhaps the most effective indictment leveled against power institutions" and "proved to be the single most important conservationist expression during the entire dispute." 52 Founded in 1912 by brothers Arthur and Paul Kellog, Survey magazine reported on a variety of progressive social issues of its day such as women's suffrage, the Harlem Renaissance, organized labor, and conservation. Over the course of its publication, Survey carried articles form notable reformers and policymakers like Harold Ickes, Francis Perkins, Henry Wallace, and Alain Locke and boasted a circulation of some 30,000. According to Cara Finnegan, the magazine was an "important outlet for progressive thought and had substantial influence on public policy." ${ }^{53}$

Although Survey billed itself as a venue for objective consideration of social issues, Wallace's article on the Falls controversy was anything but objective. With his

${ }^{50}$ Tom Wallace Papers, April-May 1929 correspondence, FHS.

${ }^{51}$ Wallace to Seth Gordon, 8 April 1929; Gordon to Wallace, 12 April 1929. Tom Wallace Papers, FHS.

${ }_{52}$ Robinson, "Conservation in Kentucky," 46.

${ }^{53}$ Cara Finnegan, "Social Welfare and Visual Politics: The Story of Survey Graphic" $<\mathrm{http}: / /$ newdeal.feri.org/sg/essay.htm> 
vigorous and terse prose, Wallace framed the issue as a battle between those who fought unselfishly for the public interest and those who, through their false propaganda and deep bankrolls, sought to manipulate both citizens and politicians alike into supporting the dam project. In language poetic enough to accompany artist Frederick Weygold's romanticized sketches of the Falls, Wallace touted the site as reminiscent "of Chateubriand's descriptions of the primeval forests of the South, in Atala." ${ }^{, 54}$ Throughout the remainder of the article, in his comfortable journalistic style, Wallace reported the long and complicated chain of events that had transpired since the power company had first applied for a license in 1924. He characterized Insull as the man who gave Chicago "heat, light, power, grand opera, and United States senators." ${ }^{.55}$ He cited the "twenty or twenty-five" lobbyists who were indicted for ethics violations in the 1928 Kentucky legislature, many of whom worked for the Insull interests. Finally, he described the questionable circumstances under which former Insull attorney Roy West had been appointed to the Federal Power Commission and confirmed "at a secret session of the Senate. $" 56$

Alluding to the broader implications of the case, Wallace addressed the broader problems inherent in the jurisdiction and structure of the Federal Power Commission. Specifically, he pointed to the enormous power of the Insull interests and the tendency for the Power Commissioners to approve perfunctorily the executive secretary's recommendations. Wallace wrote:

To our sorrow we learned that when power interests want to take over a scenic asset over which the Federal Power Commission has jurisdiction, a possibility is a decision

\footnotetext{
${ }^{54}$ Tom Wallace, "Caught in the Power Net," Survey Graphic, July 1929, 389.

${ }^{55}$ Ibid., 390.

${ }^{56}$ Ibid., 393.
} 
adverse to the state's interest made by one man [the executive secretary]. He is not a bureau head. He is not publicly or politically accountable, like a member of the cabinet. . . It is out of all reason that the power interests, probably greater than the oil interests in financial power and exceeding any preceding business combination in effrontery, electing law makers, state and national, and maintaining expensive lobbies in every state capital and in Washington, and publicity bureaus in every city and town, may deal with a single inconspicuous subordinate in Washington with hope of final results. ${ }^{57}$

According to Wallace, this faulty system whereby one man--the Executive Secretary of the Power Commission--could decide cases of immense importance indicated how Cumberland Falls was "caught in the power net."

Further emphasizing the magnitude of the case, Wallace pointed to the legal conundrum raised by Gordon's brief. "If the Federal Power Commission cannot consider scenic values," Wallace reasoned, "every state, which, like Kentucky, is without any sort of regulatory body to consider power permit applications, and every state in which a power lobby can preside over the creation of a utilities commission, will be helpless in the power net." For this reason, Wallace argued, "the Cumberland Falls case in the circumstances in which it went to the Hoover administration has national importance."

In addition to summarizing the complicated web of obstacles facing conservationists, Wallace laid out a multifaceted and convincing argument in favor of preserving the Falls. He argued that not only were the Falls an irreplaceable scenic asset to the state, but that they also represented for future Kentuckians "a great revenue producing heritage. ${ }^{, 59}$ Citing the $\$ 50,000,000$ in annual revenue that New York drew

\footnotetext{
${ }^{57}$ Ibid., 393-394.

${ }^{58}$ Ibid., 394.

${ }^{59}$ Ibid., 417.
} 
from tourism at Niagara Falls, Wallace claimed that Kentucky could draw a similar amount from its "Niagara of the South." Such arguments were not "sentimental" and "aesthetic" as many pro-dammers had characterized, but instead "far-seeing and farreaching" according to Wallace. ${ }^{60}$

Indeed, Wallace noted that construction of a dam would require enormous up front costs not to mention annual maintenance. According to Wallace, the value of the power generated would not justify the cost of the dam, especially since the Falls could be developed as a scenic attraction at such little cost. Moreover, many engineers had also warned that power dam impoundments such as the one proposed for Cumberland Falls would eventually silt up after fifty or sixty years and severely compromise the dam's capacity for long-term power production. ${ }^{61}$

Though his Survey Graphic article, Wallace addressed every aspect of the case and provided a range of arguments for preservation of the Falls that attracted a number of disparate interests. He appealed to nature lovers in his vivid descriptions of the Falls area. He appealed to state park advocates by demonstrating the economic benefits of the Falls as a scenic attraction. Finally, he appealed to both skeptics of the power trusts and critics of Kentucky politics by exposing the corrupt practices of Insull and Sampson during the affair. In short, Wallace's diverse arguments united a wide array of interests with one objective- to save Cumberland Falls.

By itself Wallace's Survey Graphic article was a masterful piece of journalism and a paragon of preservationist propaganda. Enhancing its effectiveness, however, were accompanying published statements from national conservation leaders, U.S. Senators,
${ }^{60}$ Ibid., 417.
${ }^{61}$ Ibid., 416. 
and prominent Kentuckians who pledged their support to the cause. Wallace had cleverly sent advance copies of his article to a number of his contacts and solicited statements from them for publication with the final article. If he obtained enough statements from notable individuals to demonstrate the widespread sentiment in favor of saving the Falls, Wallace reasoned that it would enhance the article immeasurably. Survey publisher Arthur Kellogg agreed and cooperated with Wallace's proposal. When the article ran in late June of 1929, it was accompanied by eighteen signed endorsements. Retired Park Service Director Stephen Mather wrote of the Falls that "no necessity for its use in power development has ever been shown.” Acting Park Service Director Horace Albright added that power development at Cumberland Falls was "too great a sacrifice for America to make for commercial progress." Idaho Senator William Borah remarked, "there is no justification for the destruction of these Falls," and President of the American Forestry Association George D. Pratt added simply, "Save them!"62 Other signers included Audubon Society President T. Gilbert Pearson, Izaak Walton League Director Seth Gordon, National Park Committee Chairman J. Horace McFarland, author Irvin Cobb, and editor and publisher Robert W. Bingham. ${ }^{63}$ With these endorsements, the article attracted more media attention than it ever could have otherwise. After learning that the Associated Press had picked up the article, Survey Graphic editor Arthur Kellog remarked "the more publicity for the article, the better for Cumberland Falls."

Not satisfied with the media support alone, Courier-Journal publisher Robert W. Bingham personally ordered a copy of the article sent to every member of Congress at his

\footnotetext{
${ }^{62}$ Ibid., 391.

${ }^{63}$ Ibid., 391.

${ }^{64}$ Arthur Kellogg to Wallace, 17 June 1929. Tom Wallace Papers, FHS.
} 
expense. ${ }^{65}$ Likewise, Ernest Oberholtzer, a conservationist who had been instrumental in establishing the Quetico-Superior preserve on the U.S. -Canada border, ordered reprints of Wallace's article for personal distribution. The Louisville Automobile Club and Cumberland Falls Preservation Association of Ohio also reprinted the article in pamphlet form for distribution. ${ }^{66}$ Before long, portions or full versions of the article with editorial comment had appeared in the Knoxville News Sentinel, the St. Louis Post Dispatch, the Emporia Kansas Gazette, the Cincinnati Star, and the Milwaukee Journal among others. The Franklin Square Subscription Agency rated the article one of its "Ten Most Outstanding Articles of the Month. ${ }^{, 67}$ As Wallace commented to duPont in late August, the article received "considerable recognition among conservationists and I hope has made us some new friends. ${ }^{" 68}$ Clearly, the media attention generated by Wallace's article pushed the momentum in favor of conservationists as the newly appointed Power Commission prepared to hear the case. Perhaps as a result of this growing preservation momentum, Secretary of the Interior Wilbur announced on August 2 that the members of the Power Commission would visit the Falls in person sometime in September or October before reaching a decision on the case. ${ }^{69}$

Later that month, James Couzens, a Republican Senator from Michigan and chairman of the Senate Interstate Commerce Committee, wrote to Wallace and acknowledged his persuasive article. Couzens noted that the article would "play a part in this committee considering the whole power problem." ${ }^{, 70}$ Indeed, just a few weeks

\footnotetext{
${ }^{65}$ Ibid., 17 June 1929.

${ }^{66}$ Wallace to Arthur Kellogg, 27 June 1919. Tom Wallace Papers, FHS.

${ }^{67}$ Hannah Gallagher, Secretary of Survey Associates, to Wallace, 19 July 1929. Tom Wallace Papers, FHS.

${ }^{68}$ Wallace to T. Coleman duPont, 31 August 1929. Tom Wallace Papers, FHS.

69 "Delay Permit for Insull," New York Times, 3 August 1929.

${ }^{70}$ James Couzens to Wallace, 22 August 1929. Tom Wallace Papers, FHS.
} 
before, Couzens had announced an investigation into the influence exercised by the private utilities on the Federal Power Commission. Wallace's vivid depiction of the extent of the "power net" had struck a cord with Couzens, prompting him to remark, "you do very naturally raise a question, and this of course should be answered.",71 When Congress reconvened for its regular session, Couzens promised to address the issue.

Meanwhile in Kentucky, attorney General James Cammack began to speak out vigorously against Governor Sampson's clandestine contract with the Insull interests. Not only was the contract illegal, Cammack alleged, but the Governor knew it was illegal and thus kept the contract a secret until the December 1928 hearings. "One cannot help being impressed with the idea that there must have been a feeling and understanding that the contract was illegal and against public policy," Cammack protested. ${ }^{72}$ With the Attorney General turning against him, Sampson's support base in Kentucky began to dwindle.

When the Power Commission finally visited the Falls on October 10, 1929, a day that the Courier-Journal described as "an ideal October day" with the Falls and the surrounding hills "in their best autumn raiment," it appeared that the balance of opinion in the case had shifted in conservationists' favor. ${ }^{73}$ Finally, it seemed, Wallace had realized his wish for the Commissioners, and for all America, to judge for themselves whether the Falls should be preserved. Initially, Wallace thought the commissioners would visit the Falls privately to avoid harassment from competing interests. When he was formally invited to join the official party, however, Wallace was a bit surprised. He

\footnotetext{
${ }^{71}$ Ibid., 22 August 1919.

72 “Accuses Governor in Kentucky Deal," New York Times, 18 August 1929, 18.

73 "Verdict Soon on Fate, Hope of Chairman," Courier-Journal, 11 October 1929, 4.
} 
promised, however, "not to harangue or harass" the commissioners. ${ }^{74}$ Along with Wallace, Park Service Director Horace Albright and American Civic Association Secretary Harlean James were the only conservationists in the 15-person "official" party. The remainder consisted of the Power Commissioners, their staff members, and consulting engineers, although Governor Sampson and Congressman John Robsion were invited to represent the pro-dam interests. ${ }^{75}$

Escorted by Governor Sampson, the commissioners left Lexington and made their way to the Falls via the 26-mile road roadway constructed by the members of the Kiwanis Club of Corbin only a few years earlier. Once they arrived at the site, Wallace and Sampson jockeyed for position with the commissioners. Standing alongside Wallace at the edge of a cliff overlooking the Falls, Secretary Hyde supposedly murmured "it is beautiful."76 Likewise, Secretary Wilbur agreed, "it is a beautiful spot . . made even more beautiful by the hills that surround it."77 Not content with the commissioners" lukewarm response, Wallace invited the suit-clad trio to climb down a 60-foot rope ladder into the gorge to get a more intimate view of the cataract. At first, Secretary Good hesitated, but at Wallace's insistence, he mounted the rope and descended. He was followed by Secretaries Wilbur and Hyde. After taking in the view, the party climbed back up the shaky rope ladder and departed above the Falls. They were then transferred

${ }^{74}$ F. E. Bonner to Wallace, 5 October 1929, Tom Wallace Papers, FHS.

${ }^{75}$ The official party included: Secretary of War James Good; Secretary of the Interior R.L. Wilbur; Secretary of Agriculture A.M. Hyde; Director of the National Park Service Horace Albright; Executive Assistant to the Secretary of the Interior, Northcutt Ely; Chief Engineer of the Power Commission, N.C. Tyler; Assistant Chief Engineer, F.K. Newcomer; Executive Secretary of the Power Commission S.E. Bonner; Governor of Kentucky, Flem Sampson; Congressman John Robsion; Chief of the Editorial Staff of The Louisville-Times, Tom Wallace; President of the Kentucky Utilities Company L. B. Harrington; Honorable R.P. Ernst; Executive Secretary of the American Civic Association Harlean James; and District Engineer for the United States Engineer's office F.S. Besson. See: Courier-Journal, 10 October 1929. 
into boats where they crossed the swift Cumberland River before returning to Lexington that evening.

Despite his promise not to harass the commissioners, Wallace clearly made every effort to ensure that they left with a favorable impression of the Falls and a clear sense of where he stood on the issue. Although the rope ladder descent and the detour by boat were seemingly spontaneous diversions, they were almost surely premeditated by Wallace to enhance the commissioner's enjoyment and memory of the trip. Wallace was well aware that Hyde had previously expressed a liking for the "outdoor life" and that Wilbur had been a noted conservationist before his stint on the Power Commission. As the Courier-Journal reported, the addition of these "strenuous items" to the visit prompted the commissioners to declare later that evening "that just such an outing was what they had hankered for." ${ }^{, 78}$ Although Secretary Good stated that the Commission had not discussed a decision in the matter, conservationists had every reason to interpret the visit as a success. Indeed, a site that was relatively unknown to Kentuckians before 1927 had now been showcased to three members of the President's cabinet and virtually millions of newspaper readers who read about the visit in the next day's paper. A favorable decision seemed just around the corner.

Five weeks later in November, however, strange and unforeseen events threw a wrinkle into the case. After undergoing an emergency appendectomy, Secretary Good suddenly died from blood poisoning. ${ }^{79}$ With Good's tragic death leaving a vacancy on the Commission, Secretaries Wilbur and Hyde decided to postpone consideration of the

76 “Federal Power Body Lauds Falls, Hopes For Decision Soon," Courier-Journal, 11 October 1929.

${ }^{77}$ Ibid., 11 October 1929.

${ }^{78}$ Ibid., 11 October 1929. 
Falls case to see if the Kentucky legislature might address the controversial issue in the upcoming 1930 session.

While the Commission's refusal to rule on the case exhausted both conservationists and dam advocates alike, who had spent most of the year gearing up for the decision, it did have long-term benefits for conservationists. Because the threat of a decision by the Commission had a national impact far beyond Kentucky's borders, it enabled Wallace to attract more attention to the Falls than he might have otherwise. The broader significance of the case also encouraged Wallace to develop more diverse arguments in favor of preserving the Falls, instead of repeating the usual scenic beauty arguments. Therefore, when the case returned to the General Assembly in early 1930, the intense interest that Wallace had attracted during the previous year and a half brought pressure to bear both on the Kentucky legislature and on local public sentiment. As Sampson's approval rating plummeted due to a combination of factors including his position on the Falls, the atmosphere looked ripe for a favorable decision in 1930.

\footnotetext{
${ }^{79}$ Robinson, “Conservation in Kentucky,” 45.
} 


\section{CHAPTER IV \\ VICTORY AND AFTERMATH, 1930 TO PRESENT.}

By the end of 1929, Wallace had attracted considerable national attention to the Falls case. After the Power Commission declined to rule on the permit, however, the case became a state matter once again. If the Falls were to be preserved once and for all, then the state legislature had to take action on their behalf. Even though the Power Commissioners lauded the beauty of the Falls during their visit in October, Wallace recognized even before the visit that they might be legally handcuffed from refusing the permit on grounds that the dam would impact the scenic beauty of the Falls. Without federal sanction to stop the dam, the state legislature provided the last line of defense. “Unless we could get a legislature on our side," Wallace wrote to Attorney General James W. Cammack, "we should have no means of preventing the construction of a power dam." Likewise, in September 1929 Izaak Walton League President Henry B. Ward advised that, if the Power Commission delayed their decision, it was "necessary for further activity to start from the state itself." ${ }^{2}$ To be successful, Ward wrote to Wallace, "it must be initiated by or through you, and must be led by men ... who command public attention."3 Thus, when the Power Commission did postpone the case indefinitely in late 1929, Wallace brought a full-scale fight back to Kentucky. Unlike previous state

\footnotetext{
${ }^{1}$ Wallace to J.W. Cammack, 23 August 1929. Tom Wallace Papers. The Filson Historical Society (FHS), Louisville, Ky.

${ }^{2}$ Henry B. Ward to Wallace, 23 September 1929. Tom Wallace Papers, FHS.
} 
lobbying campaigns, however, this time he relied on a healthy support base as well as a growing "tidal wave of anti-Sampson feeling." " In lobbying the state legislature, Wallace and his supporters argued, contrary to Sampson's appeals, that saving the Falls was in Kentucky's best interest, both as a superb natural site and as a moneymaking tourist attraction. Eventually they succeeded.

While previous attempts at state-level activism had floundered, by 1930 there existed a coordinated corps of conservationists in the state eager to lobby for protective legislation. In early January, the Cumberland Falls Preservation Association formed a special executive committee with the sole purpose of persuading state legislators to accept the duPont offer. ${ }^{5}$ The committee included the usual cadre of journalists, state park advocates, and automobile club members, but more importantly, it now included bankers and businessmen from across the state who were beginning to join Wallace in proclaiming "the revenue value of scenic assets."

According to Wallace, Governor Sampson had already "rounded up all of the people on the power project side in southeastern Kentucky." ${ }^{\prime 7}$ To counter those efforts, Wallace suggested to D.F. Brown, President of the Farmers State Bank of London, that "if the legislature could get before it views of a group of substantial businessmen of your section, ... it would be a great help to the cause." ${ }^{\prime 8}$ After collecting signatures and statements from several influential businessmen in the vicinity of the Falls, Wallace

\footnotetext{
${ }^{3}$ Ibid., 23 September 1929.

${ }^{4}$ Robert F. Sexton, "Flem D. Sampson," in Lowell Harrison, ed., Kentucky Governors (Lexington, KY: University of Kentucky Press, 2001), 162.

${ }^{5}$ Courier-Journal, 10 January 1930.

${ }^{6}$ George W. Robinson, "Conservation in Kentucky: The Fight to Save Cumberland Falls, 19261931," Register of the Kentucky Historical Society, v. 81 no. 1 (Winter, 1983), 48-49; Courier-Journal, 23 January 1930.

${ }^{7}$ Wallace to D.F. Brown, 20 January 1930. Tom Wallace Papers, FHS.

${ }^{8}$ Ibid., 20 January 1930.
} 
submitted a petition to the legislature to illustrate that respected businessmen in the state now favored preservation. ${ }^{9}$

In addition to the petition, on January 22 Wallace engaged in a debate with Judge H.H. Tye over the dam project organized by the Louisville Women's Club. Although the two "covered familiar ground" Wallace's considerable debate skills and ability to arouse indignation towards the dam project and the corruption behind it favorably impressed the club members. ${ }^{10}$ Following the debate, the Women's Club joined with the Lexington Kiwanis Club and several other business and professional clubs in issuing resolutions against the dam project. ${ }^{11}$ According to George Robinson, "conservationists may have been at one time disorganized and moneyless, .. . but they were anything but that in early 1930."12 By late January 1930, the momentum had clearly shifted in conservationists' favor while pro-dammers were "disoriented and defensive."13

When the Kentucky General Assembly reconvened in January, the Cumberland Falls issue took precedence over all other concerns even amidst the mounting turmoil of the Depression. As state senator and later Governor Albert B. "Happy" Chandler remembered, it was "the outstanding legislative struggle of the time." ${ }^{14}$ The New York Times reported that the contest "promises to be bitter."15 The final showdown began when Representative John Y. Brown of Lexington introduced a bill in early January to

\footnotetext{
${ }^{9}$ Wallace to Henry C. Colgan, 31 January 1930. Tom Wallace Papers, FHS.

${ }^{10}$ Robinson, "Conservation in Kentucky," 49.

${ }^{11}$ Courier-Journal, 23 January 1930.

12 Ibid., 49.

${ }^{13}$ Robinson, "Conservation in Kentucky," 48.

${ }^{14}$ Interview with Albert B. "Happy Chandler," as quoted in George Robinson, "Conservation in
} Kentucky," 48. Robinson also correctly notes that other studies of the 1930 General Assembly tend to focus on the "ripper legislation" that deprived the Governor of many of his powers rather than the Cumberland Falls issue. One source that does point to Cumberland Falls as "the most controversial" issue during the Sampson administration is Robert F. Sexton, "Flem D. Sampson," in Lowell Harrison, ed., Kentucky Governors, 162. 
allow the State Park Commission to condemn the Falls property and accept the duPont gift. In essence, the bill was a restatement of previous condemnation bills. This time, however, the General Assembly recognized the intense interest voiced by both conservationists and power dam advocates in the case and they postponed deliberations on the matter until February in order to give both sides ample time to clarify their positions. $^{16}$

In the meantime, however, New York businessman and Kentucky native Frederick Wallis invited legislators and those interested in preserving the Falls to attend an impromptu promotional banquet on January 29 at the Capital Hotel in Frankfort. Described as "more a habitual supporter of causes than a pure conservationist," Wallis had just returned to his home state after a successful business career in New York. ${ }^{17} \mathrm{He}$ used his prominence to invite legislators, judges, journalists, and other notables to attend the banquet and to discuss the merits of the duPont proposal. With over 500 in attendance including all but three legislators, the dinner was a rousing success for conservationists. Speaking at the banquet, duPont spokesman John W. Barr presented the Senator's gift as an unsolicited and purely philanthropic gesture to his native state in contrast to the suspicion aroused by the Sampson-Insull contract. In doing so, Barr refuted the power company's allegations that duPont somehow had hidden business motives in Kentucky. Not surprisingly, pro-dam advocates quickly denounced the banquet as a calculated ploy by conservationists to influence legislators. As such, they

15 "Cumberland Falls Issue in Kentucky: Contest over Development of Water Power Promises to be Bitter in Legislature," The New York Times, 19 January 1939, 56.

${ }^{16}$ Ibid., 19 January 1930.

${ }^{17}$ Robinson, "Conservation in Kentucky," 49-50. 
encouraged the senate to condemn the banquet formally and to censure every legislator in attendance. The senate refused the proposal. ${ }^{18}$

Thus, by early February 1930, the activities and statements of the state's lawmakers indicated their growing support for preserving the Falls. As Wallace indicated on February 10, the state's newspapers were also beginning to side with conservationists. Wallace's survey of 112 statewide newspapers revealed that 81 supported preservation. Forty-two of the state's editors also publicly endorsed the duPont proposal. ${ }^{19}$ Likewise, the Courier-Journal's survey of 1200 "representative Kentuckians" received 800 responses and "all but four were for the duPont gift." 20 While it was still uncertain exactly how most Kentuckians felt about the issue, the news media portrayed public opinion as favorable to the park project. Although, there was no reason to doubt such assertions, the paper's obvious bias against Sampson and Insull surely influenced their estimates.

When the duPont acceptance bill finally came before the House on February 18, representatives returned with a surprising 63-30 vote to approve the duPont gift. After similar bills had failed in the 1926 and 1928 sessions, the vote margin in the House was an indicator that political opinion had shifted even if public opinion had not. A companion bill granting the state the power of eminent domain over the Falls tract also passed by an overwhelming 92-1 margin, with only Thomas H. Troxel, a McCreary County Republican in opposition. Although the first bill approved duPont's offer to purchase the 2,200-acre Falls tract for $\$ 230,000$ explicitly for park purposes, it also contained an amendment stating that the state could use the site for power purposes "at

\footnotetext{
18 Ibid., 49-50.

${ }^{19}$ Robinson, "Conservation in Kentucky," 49.
} 
some future time subject to action of the General Assembly."21 Although the amendment worried some conservationists, Wallace later noted that it "was agreed to because it satisfied a few of our law makers who wished the state should be abundantly cautious about surrendering its sovereign rights.",22 Besides, Wallace argued, "it would be impractical for the state to build an isolated power plant at Cumberland Falls and there is no sentiment in behalf of any general program of state power plant making."23

Summarizing the significance of the House vote, the Courier-Journal reported:

The public opinion of every section of the state, including Southeastern Kentucky, is overwhelmingly in favor of accepting General duPont's generous offer and the House of Representatives this afternoon responded in a noble, patriotic manner. $^{24}$

While the House voted convincingly in favor of preservation, conservationists feared a closer vote in the Senate. Somewhat surprisingly, however, four Republicans crossed the aisle enabling the Senate to pass the bill by a 21-16 margin on February 26. Although conservationists expected a Sampson veto, Wallace recognized that the Senate's margin was sufficient to override it. In response, Wallace declared the decision "a victory of the sentiment of a State over one of the most highly organized and insolent lobbies that ever attempted to control a legislature." 25 Moreover, Wallace reassured his supporters that not only would Cumberland Falls "be worth millions to Kentucky as a revenue producer," but it would also "build roads in a section of Kentucky between Mammoth Cave and Cumberland Falls which is greatly in need of development." ${ }^{26}$ As a

\footnotetext{
${ }^{20}$ Wallace to Paul Kellogg, 10 February 1930. Tom Wallace Papers, FHS.

${ }^{21}$ Courier-Journal, 19 February 1930.

${ }^{22}$ Wallace to Miller Bennett, 24 March 1930. Tom Wallace Papers, FHS.

${ }^{23}$ Ibid., 24 March 1930.

${ }^{24}$ Ibid., 19 February 1930.

${ }^{25}$ Courier-Journal, 26 February 1930.

${ }^{26}$ Ibid., 26 February 1930.
} 
result, the park promised to "be worth far more to Southeastern Kentucky than any power plant could be worth.",27

As expected, Governor Sampson registered his veto shortly after the Senate vote, arguing that the decision deprived Kentucky of much needed economic development. On March 7, however, the House of Representatives promptly overrode the veto by a 60-23 vote, as every Democrat upheld the duPont gift. According to the state constitution, the Senate had to register a 20 -vote minimum to override a veto. Twice the Senate returned majority votes, but fell short of the 20 votes required to override. After adjourning for a weekend filled with furious activity on both sides, the Senate reconvened on March 10, and before a crowded and anxious chamber of visitors, exactly 20 senators voted to override Sampson and accept the duPont gift once and for all. ${ }^{28}$

Finally, conservationists sensed victory. Even though there remained a remote possibility that the Federal Power Commission could grant the permit, precedent indicated that the Commission would respect the state's decision in the matter and dismiss the case altogether. ${ }^{29}$ After nearly five years of tireless protest, conservationists had prevailed. Following the decision, Wallace received countless letters of praise and congratulations from across the country, each recognizing his singular role in the campaign. Survey Graphic editor Arthur Kellogg quipped, "they ought to rename the Falls after you. ${ }^{, 30}$ On April 20, The New York Times reported on the historic decision affecting the Cumberland River, "whose destiny has so long hung in the political balance." After the senate vote, the Times declared that "to the general American

\footnotetext{
${ }^{27}$ Ibid., 26 February 1930.

${ }^{28}$ Courier-Journal, 11 March 1930.

${ }^{29}$ Robinson, "Conservation in Kentucky," 53.
} 
satisfaction, it will continue its meanderings, peaceful and serene through the coming centuries, undisturbed by turbines, transformers, generators and such-like fixtures of hydroelectric development." 31 The article served as a fitting epitaph to the bitter controversy that had raged for five years and aroused the indignation of conservationists everywhere.

Although the March 11, 1930 vote to override Sampson's veto effectively marked the end of Wallace's preservation campaign, a series of complications delayed the final purchase of the property until January 1931. For one, an obstinate Governor Sampson still headed the State Park Commission and by virtue of his title he held the final authority to purchase the Falls tract from the Insull interests. Problematically, Sampson had already signed a contract to endorse the Insull permit application before the Power Commission. Even though it was evident that the Power Commission would respect the state's decision in the case, Sampson and the Insull interests continued to push the case at the Federal level. ${ }^{32}$ Their stubbornness aggravated Wallace and other conservationists who wanted to put the controversy behind them.

Indeed, in the aftermath of the Cumberland Falls decision, the General Assembly handed Governor Sampson a tremendous blow by passing "ripper" legislation that deprived him of much of his statutory authority and appointing power. ${ }^{33}$ According to Robert F. Sexton, when the state legislature dismissed in the spring of 1930, "Sampson had lost control of the state government."34 Said to have "a wide reputation as a ladies'

${ }^{30}$ DuPont to Wallace, 25 February 1930; Albright to Wallace, 26 February 1930; Kellogg to Wallace, 7 April 1930. Tom Wallace Papers, FHS.

${ }^{31}$ The New York Times, 20 April 1930.

${ }^{32}$ Robinson, "Conservation in Kentucky," 53.

${ }^{33}$ Sexton, "Flem D. Sampson," in Lowell Harrison, ed., Kentucky Governors, 162.

${ }^{34}$ Ibid., 162. 
man," Sampson now had nothing to do but "produce Kentucky Colonels and seduce Kentucky women," according to John Ed Pearce. ${ }^{35}$ As the Lexington Herald reported, the 1930 General Assembly "left Sampson shorn of his locks."36

After three months passed and Sampson's Park Commission still refused to take steps to secure the property, Attorney General Cammack opened negotiations with the power company under the authority granted by the 1930 General Assembly. In his defense, Sampson alleged that the state had never received any of the funds promised by duPont. Despite the Governor's persistent claim, however, Cammack offered the power company $\$ 200,000$ for 593 acres at the Falls. Insull representatives promptly rejected the offer, citing that the value of the land far exceeded that amount. In response, Cammack brought suit in Whitley County on July 29 to formally condemn the property as the 1930 decision allowed. Before hearing the suit, Whitley County Judge M.M. Criscillis appointed three appraisers to determine the actual value of the land. While two appraisers valued the tract at $\$ 1,186,000$, another returned an estimate of only $\$ 190,000$. Clearly, interested parties had affected the appraisals. Due to the discrepancy, Judge Criscillis postponed his decision and set a date for a final hearing in January $1931 .^{37}$ In the meantime, however, Wallace and other conservationists around the state began lobbying for the completion of the Eastern National Park-to-Park highway project, a federal highway program intended to link Mammoth Cave to the Great Smoky Mountains and Shenandoah Valley parks via the Cumberland Gap. Wallace and Attorney General Cammack suggested to federal authorities that the highway should

\footnotetext{
35 John Ed Pearce, Divide and Dissent: Kentucky Politics, 1930-1963 (Lexington, KY: University of Kentucky Press, 1987), 27.

36 Ibid., 27.

${ }^{37}$ Robinson, "Conservation in Kentucky," 54-55.
} 
include a section running from Corbin to Cumberland Falls. Writing to Representative M.H. Thatcher in August, Wallace remarked "I drove over the proposed road from Corbin to Cumberland Falls a few days ago and it will surely make a beautiful link in the highway. ${ }^{״ 38}$ Although Congress did not finally allocate funding for the project until April 1931, the highway proposal had already received an enthusiastic reception in the state media by November 1930. As a result, the project further energized advocates of a state park at the Falls and further curbed any hope that Sampson and Insull maintained for a power dam. ${ }^{39}$

The onset of the Depression in 1930 and 1931 also contributed to changed attitudes and policies, especially in Kentucky where a severe drought in 1930 prompted eighty-six counties to apply for federal assistance. In the rich coalfields around the Falls area, unemployment jumped to 40 percent. ${ }^{40}$ Whereas in the 1920 s state parks and outdoor recreational facilities appealed to the "idle rich," they attracted during the Depression a broader spectrum interests. As Paul Sutter argues, "During the 1920s, the nation's affluence produced increased leisure time; during the 1930s, increased "leisure" was the result of the Depression itself." 41 Thus, to fill the "leisure" and "idle" time brought on by the Depression, the Federal government turned to federal employment and recreation programs. During the last two years of his presidency Hoover and an increasingly Democratic congress reluctantly initiated public works projects such as road building that Franklin Roosevelt would greatly expand during the New Deal years. In

\footnotetext{
${ }^{38}$ Wallace to Rep. Maurice Thatcher, 1 August 1930, Tom Wallace Papers, FHS.

${ }^{39}$ Robinson, "Conservation in Kentucky," 55; Maurice Thatcher to Wallace, 6 April 1931. Tom Wallace Papers, FHS.

${ }^{40}$ Sexton, "Flem D. Sampson," in Lowell Harrison, ed., Kentucky Governors, 162.

${ }^{41}$ Paul Sutter, Driven Wild: How the Fight Against Automobiles Launched the Modern Wilderness Movement (Seattle, WA: University of Washington Press, 2002), 48.
} 
sum, these new developments favored public park and highway projects over private developments.

With the January 1931 court date pending, Attorney General Cammack continued negotiations with the Cumberland River Power Company to purchase the Falls property. Realizing that the widespread support for the state park and highway projects eliminated all probability of a power dam at the site, the Insull interests finally offered to sell the tract for $\$ 400,000$, roughly twice what duPont had initially offered. Although duPont died from a long bout with throat cancer in November 1930, his widow agreed to provide the $\$ 400,000$ requested by the CRPC. After attorneys finally sealed the deal, the Courier-Journal reported on January 31, 1931:

Cumberland Falls, the second largest waterfall in the United States east of the Mississippi River, became the property of the Commonwealth of Kentucky, to be preserved as a perpetual state park, it was announced following an amicable agreement between leaders in a sixyear fight that assumed national proportions. ${ }^{42}$

In the years that followed, Cumberland Falls grew into one of Kentucky's most visited attractions. Within three months of the completion of Federal Route 25 from Corbin to the Falls in 1931, some 50,000 people visited the park. During the mid-1930s, CCC workers constructed numerous buildings on the site, including a two-story rustic lodge, fifteen cabins, and an assortment of roads, trails, and picnic facilities. Although in 1965 the Corps of Engineers proposed another power project for the Falls, conservationists led by Robert Blair of Corbin reestablished the Cumberland Falls

\footnotetext{
${ }^{42}$ Courier-Journal, 31 January 1931.
} 
Preservation Association and easily defeated the plan. ${ }^{43}$ Today, Cumberland Falls State Resort Park is surrounded by the Daniel Boone National Forest and continues to attract fisherman, rafters, hikers, and other outdoor enthusiasts, many of whom stay in the park's DuPont Lodge, which offers stunning views of the river valley. With an estimated 700,000 to 1 million visitors annually, the park remains one of Kentucky’s most visited and profitable state parks. ${ }^{44}$

Although the final purchase and "amicable agreement" reached in January 1931 officially marked the end of the "Cumberland Falls Fight," as Wallace remembered it, it did not end his association with the Falls or with conservation interests. Interestingly, Wallace's vision for a State Park at the Falls evolved considerably in the aftermath of the fight. While he had initially supported road construction, scenic tourism, and recreation at the Falls, in later years Wallace increasingly fought to preserve the park's wilderness qualities. In many ways, he had kept the case alive up to 1930 by appealing to anyone who would listen, whether state park advocates, economists, or merely those distrustful of corruption in federal and state governments. With the future of the Falls secure, Wallace no longer had to please all of the interests which had united behind the park, and he turned his attention to promoting his primary objective, wilderness preservation. Indicating this attitude Wallace remarked after the final purchase that "the chief value of the acquisition is as a wilderness area aside from the water falls. There is nothing so important as keeping it in its wilderness condition."

\footnotetext{
${ }^{43}$ Robinson, "Mr. Cumberland Falls," Border States: Journal of the Kentucky-Tennessee American Studies Association, no. 8 (1991). Available online at $<$ http://spider.georgetowncollege.edu/htallant/border/bs8/robinson.htm $>$

44 “Cumberland Falls State Park," <http://www.state.ky.us/agencies/khc/cumber.htm>

${ }^{45}$ Ibid., 31 January 1931.
} 
Wallace's support for "wilderness preservation" after the Falls purchase paralleled the broader developments in the so called "wilderness movement" that culminated with the founding of the Wilderness Society in $1935 .{ }^{46}$ Moreover, the shifting policital and social pressures of the 1930s increasingly made wilderness advocacy a viable form of activism, whereas in the 1920s wilderness preservation was overshadowed by recreational and tourist concerns. As part of his desire to keep the park primarily a wilderness area, Wallace resisted a number of "improvements" proposed for the park. ${ }^{47}$ For example, in 1933 he criticized plans to construct additional roads in the park and plans for a 600 -foot automobile and pedestrian bridge over the river near the Falls. ${ }^{48}$ Later, he protested the sale of concessions in the park, which he believed were "making Mona Lisa the background of a Hot Dog Stand." When plans were introduced to build more tourist accommodations, Wallace again insisted that they be located outside the park boundaries. ${ }^{49}$ Although he fought vigorously to keep CCC camps in Kentucky during the late 1930s, by 1937 he accused overzealous CCC workers of "defacing" the park's wilderness areas. ${ }^{50}$ In short, Wallace had successfully saved the Falls by demonstrating their capacity to generate tourist revenue, but when tourists began to pour in by the thousands he feared that the park was being "commercialized" and appreciated to death. As Paul Sutter argues, this backlash against auto tourism and recreation marked

\footnotetext{
${ }^{46}$ Sutter, Driven Wild, 3-18.

${ }^{47}$ Wallace to J.W. Cammack, 10 February 1932. Tom Wallace Papers, FHS. Wallace wrote to Cammack, "I think it immensely important to get Cumberland Falls protected from vandalism and kept in its present condition until we have a better Park Commission than we have had and that nothing is more important than avoiding unwise 'improvement'."

${ }^{48}$ Wallace to F.V. duPont, 12 July 1933. Tom Wallace Papers, FHS.

${ }^{49}$ Wallace to Horace Albright, 28 April 1932. Tom Wallace Papers, FHS.

${ }^{50}$ Wallace to Harlean James, 28 September 1937. Tom Wallace Papers, FHS.
} 
a significant shift towards wilderness advocacy that characterized much of conservation activism into the 1940 s and beyond. ${ }^{51}$

From the contours of his later activism, then, it is clear that Wallace did not adhere to a monolithic understanding of conservation. His arguments about wilderness and its preservation evolved considerably with time and varied depending on certain projects and agendas. As a journalist and an astute observer of social and political trends, Wallace kept pace with the impulses in the larger conservation movement around him. Thus, while "wilderness" advocacy was politically and culturally bankrupt during most of the Cumberland Falls fight, it later received a healthy following after the 1930s, prompting Wallace to shift arguments and strategies accordingly.

After the Cumberland Falls fight and largely as a result of his success there, Wallace rose to national prominence as a conservationist. In 1934 he won the Pugsley Silver Medal from the American Scenic and Historic Preservation Society for his victory at the Falls, and later that year he was nominated for a Pulitzer Prize. During the 1940s, he served as President and Director of the Izaak Walton League and Chairman of the National Conference on State Parks. From 1944 to 1950, Wallace sat on the fourteenmember National Parks Service Advisory Board, an appointment he received from Secretary of the Interior Harold Ickes. As his correspondence reveals, Wallace maintained close relationships with Park Service Directors such as Horace Albright, Arno Cammerer, and Newton Drury, as well as with Interior Harold Ickes. In his various posts during the 1940s and 1950s Wallace promoted federal stream pollution legislation and fought to protect national and state parks from "artificial improvements" of all kinds. During the early 1950s Wallace battled extensively against the Echo Park Dam proposed

\footnotetext{
${ }^{51}$ Sutter, Driven Wild, 3-18.
} 
for Dinosaur National Monument in Colorado and the construction of interstates through Louisville's Cherokee and Seneca Parks. Of the importance of parks Wallace declared, "they are the crown jewels of our kingdom of democracy and enlightenment." ${ }^{, 52}$ In the spring of 1950, he issued a call to all conservationists that, above all, "preservation is our purpose. ${ }^{, 53}$

Clearly, the Cumberland Falls episode between 1925 and 1931 represents only one particular moment in Wallace's long career as a conservationist and one particular phase of the larger conservation movement. But examining Wallace's arguments and strategies at Cumberland Falls provides much needed insights into how successful conservationists responded to specific social and political trends of the 1920 s, a time which many historians have described as a low point in conservation activism. Indeed, as Wallace admitted in 1954, "I set out on a project in Kentucky and no one in Kentucky agreed with me. That was the effort to save Cumberland Falls." ${ }^{54}$

Broadly, Wallace eventually succeeded at the Falls by developing three main arguments and strategies, each of which responded directly to contemporary developments of the 1920s. First, he praised the aesthetic value of the Falls at a time when middle class Americans were beginning to appreciate and have access to such sites for the first time. Second, he demonstrated the "hard cash" tourist value of a state park at the Falls, only made possible by the rapid expansion in auto tourism during the late 1920s. Third, he exposed the corruption of both the Insull interests and Governor Sampson, linking it to the emerging national distrust for large private utility corporations

\footnotetext{
52 Tom Wallace, "Preservation is our Purpose," The Living Wilderness (Washington, D.C.: The Wilderness Society, no. 32, Spring 1950), 19-20.

${ }^{53}$ Ibid, 19-20.

54 Tom Wallace, "Should Parks be Sacrificed," American Planning and Civic Annual (1954), 128.
} 
and corrupt lobbying practices. As a prominent journalist and speaker, Wallace also possessed the ability to publicize and disseminate these arguments more effectively than most conservationists at the time. For this reason, his crusade at Cumberland Falls is particularly revealing.

With his three-pronged attack at Cumberland Falls, Wallace blurred the boundaries between "preservationism" and "utilitarianism" that divided conservationists like John Muir and Gifford Pinchot a generation before. His activism also debunks a false perception that preservation philosophy somehow evolved steadily irrespective of outside pressures. Instead, as Robert Weyeneth argues, "the American philosophy of preservation evolved in fits and starts.",55

Unlike "heroes" of conservation like John Muir, Gifford Pinchot, and Aldo Leopold who are often depicted as having very specific approaches to conservation, Wallace was an opportunist, seizing whatever philosophy or argument could advance his particular agenda most effectively. In the end, it was exactly that strategy that enabled him to save one of Kentucky's most cherished assets from destructive encroachment when probably no other approach would have succeeded. Therefore, Wallace's flexibility and adaptability as an activist contributed to his success at Cumberland Falls when conservation had fallen out of favor with many Americans. For this reason, his example at Cumberland Falls is a valuable model of successful activism during the understudied period of the late 1920s. By resisting single-minded and dogmatic approaches to conservation, Wallace built a broad coalition of support for the Falls that

${ }^{55}$ Robert R. Weyeneth, "National Parks and Preservation," in Encyclopedia of American Social History, vol. III (New York: Charles Scribner's Sons, 1993), 1699. 
attracted people with many different motives. Although many united behind his preservation crusade, it was ultimately Tom Wallace who hung the moonbow. 


\section{REFERENCES}

Primary Sources:

American Planning and Civic Annual. Harrisburg, PA: Mount Pleasant Press, 1930, 1944, 1946, 1949, 1950. 1951, 1954.

Byllesby Engineering and Management Corporation. Power Development at the Ohio River Falls. Pamphlet, 1926. The Filson Historical Society, Louisville, Kentucky.

The Courier Journal, 1925-1931.

Engineers and Architects Club of Louisville. Report of the Special Committee on the Cumberland River Falls Power Project. Report, 16 November 1926. The Filson Historical Society, Louisville, Kentucky.

James, Harlean. "How Corbin Discovered Cumberland Falls." The Review of Reviews, February, 1929, pgs. 72-74.

The New York Times, 1925-1931.

Noel, Lois Purcell. Cumberland Falls. Pamphlet, 1932. The Filson Historical Society, Louisville, Kentucky.

Reid, Kenneth A. "Tom Wallace: National President." Outdoor America, vol. 11, no. 3 (March-April 1946), 2.

Tom Wallace Papers, 1925-1960. The Filson Historical Society, Louisville, Kentucky.

“Uncle Tom Steps Down.” Time, 23 August 1948.

Wallace, Tom. "Caught in the Power Net." The Survey. Vol. LXII, no. 7 (July 1, 1929), 389-394, 416-417. . "Editor's View of Conservation Education." Outdoor America (JulyAugust 1944), 4-5. 
. "Preservation is our Purpose." The Living Wilderness. no. 32 (Spring 1950), 19-25.

145-148.

"The Case of Cumberland Falls." American Forests (March, 1926),

. Tell Me Not in Mournful Numbers. Unpublished autobiography held at The Filson Historical Society, Louisville, Kentucky.

Williamsburg Commercial Club. Facts about Cumberland Falls. Date unknown, ca. 1926. The Filson Historical Society, Louisville, Kentucky.

$\underline{\text { Books and Articles }}$

Blakely, George T. "Kentucky Youth and the New Deal." The Filson Club History Quarterly vol. 60, no. 1 (January 1986).

Brenner, Marie. House of Dreams: The Bingham Family of Louisville. New York: Random House, 1988.

Clark, Thomas D. History of Kentucky. Ashland, KY: Jesse Stuart Foundation Press, 1992.

Clepper, Henry, ed. Leaders of American Conservation. New York: The Ronald Press Company, 1971.

Emery, Michael et al. The Press in America: An Interpretive History of the Mass Media, $9^{\text {th }}$ ed. Boston: Allyn and Bacon, 2000.

Finnegan, Cara. "Social Welfare and Visual Politics: The Story of Survey Graphic." $<$ http://newdeal.feri.org/sg/essay.htm $>$

Fox, Stephen. John Muir and His Legacy: The American Conservation Movement. Boston: Little, Brown and Company, 1981.

Gottlieb, Robert. Forcing the Spring: The Transformation of the American Environmental Movement. Washington, D.C.: Island Press, 2005.

Harrison, Lowell, ed. Kentucky Governors. Lexington: University of Kentucky Press, 2001.

Harvey, Mark W.T. A Symbol of Wilderness: Echo Park Dam and the American Conservation Movement. Albuquerque: University of New Mexico Press, 1994. 
Hays, Samuel P. Explorations in Environmental History. Pittsburgh, PA: University of Pittsburgh Press, 1998.

Hendricks, Rickey L. "The Conservation Movement: A Critique of Historical Sources." The History Teacher, vol. 16, no. 1 (November 1982), 77-104.

Jacoby, Karl. Crimes Against Nature: Squatters, Poachers, Thieves, and the Hidden History of American Conservation. Berkeley: University of California Press, 2001.

Kleber, John E., et al. Kentucky Encyclopedia. Lexington: University of Kentucky Press, 1992. Press, 2001.

Maher, Cornelius M. Planting More than Trees: The Civilian Conservation Corps and the Roots of the American Environmental Movement, 1929-1942. Dissertation. New York University, 2001.

Miller, Char. Gifford Pinchot and the Making of Modern Environmentalism. Washington, D.C.: Island Press, 2001.

Minteer, Ben A., and Robert E. Manning, eds. Reconstructing Conservation: Finding Common Ground. Washington, D.C.: Island Press, 2003.

Mulligan, James H. "In Kentucky.” Postcard. The Filson Historical Society, Louisville, Kentucky.

Nash, Roderick Frazier. Wilderness and the American Mind, $4^{\text {th }}$ edition. New Haven: Yale University Press, 2001.

Pearce, John Ed. Divide and Dissent: Kentucky Politics, 1930-1963. Lexington: University of Kentucky Press, 1987.

Pursell, Caroll W., ed. From Conservation to Ecology: The Development of Environmental Concern. New York: Thomas Y. Crowell Company, 1973.

Robinson, George W. "Conservation in Kentucky: The Fight to Save Cumberland Falls, 1926-1931." Register of the Kentucky Historical Society, v. 81 no. 1 (Winter, 1983), 25-58.

. "Mr. Cumberland Falls." Border States: Journal of the KentuckyTennessee American Studies Association, no. 8 (1991) 
Salmond, John A. The Civilian Conservation Corps, 1933-1942: A New Deal Case Study. Durham, NC: Duke University Press, 1967.

Schudson, Michael. Discovering the News: A Social History of American Newspapers. New York: Basic Books, Inc., 1978.

. The Power of News. Cambridge: Harvard University Press, 1995.

Shabecoff, Philip. A Fierce Green Fire: The American Environmental Movement. Washington, D.C.: Island Press, 2003.

Shi, David. The Simple Life: Plain Living and High Thinking in American Culture. Athens: University of Georgia Press, 1985

Smith, Langdon Jr. The Democratization of Nature: State Park Development During the New Deal. Dissertation. University of Kansas Dept. of Geography, 2002.

Steinberg, Ted. "Down to Earth: Nature, Agency, and Power in History." American Historical Review vol.107 no. 3 (June 2002).

Steinberg, Ted. Down to Earth: Nature's Role in American History. New York: Oxford University Press, 2002.

Sutter, Paul S. Driven Wild: How the Fight against Automobiles Launched the Modern Wilderness Movement. Seattle: University of Washington Press, 2002.

Swain, Donald C. Wilderness Defender: Horace M. Albright and Conservation. Chicago: University of Chicago Press, 1970.

Tindall, George and David Shi. America: A Narrative History. New York: W.W. Norton and Company, 2000.

Weyeneth, Robert R. "National Parks and Preservation," in Encyclopedia of American Social History, vol. III. New York: Charles Scribner's Sons, 1993. 


\section{CURRICULUM VITAE}

NAME: $\quad$ Noah Garland Huffman

ADDRESS: 1904 Dorothy Ave. \#3

Louisville, KY 40205

DOB: $\quad$ Louisville, Kentucky - February 21, 1981

EDUCATION: $\quad$ B.A., History/Latin American Studies, magna cum laude Furman University, Greenville, South Carolina.

1999-2003

M.A., History

University of Louisville

2003-2005

HONORS/AWARDS:

Thomas Hamilton Graduate Scholarship, University of Louisville, 2004

Phi Beta Kappa, Furman University, 2003.

Alumni Award for Academic Excellence, History Dept., Furman

University, 2003.

Gilpatrick Scholarship in History, Furman University, 2002.

Phi Alpha Theta, 2002.

WORK EXPERIENCE:

The Filson Historical Society, Louisville, Kentucky

Special Collections Assistant/Archivist, May 2004-Present

Intern, January 2004-May 2004

University of Louisville

Student Transcription Assistant, Oral History Center, Fall 2004

The Commonwealth Group, lobbyists, Louisville, Kentucky

Intern, Summer 2001, 2002

PROFESSIONAL SOCIETIES:

Kentucky Council on Archives, Spring 2005-present

PUBLICATIONS:

“Tom Wallace, 1874-1961," in The Filson (Summer 2005) 
"William S. Hawkins, Prisoner and Poet of Camp Chase, Ohio," in The Filson (Fall 2005)

\section{INVITED PRESENTATIONS:}

"Agitator: Tom Wallace and the Conservation Movement, 1925-1960," at joint meeting of Kentucky Council on Archives and ARMA, Frankfort, Kentucky, May 13, 2005. 